\title{
الأهمية المالية والاقتصادية والخدمية للثروة الحيوانية في ولاية بغداد
}

\author{
أ.م.د. سامي ناظم حسين المنصوري \\ جامعة القادسية
}

p) $91 \leq-1199$

شكلت الثروة الحيوانيـة في الدولة العثمانية وولاياتها المتعددة احد الركائز الرئيسـة للاقتصـاد

العثـاني ، فامتلكت ولايـة بغداد خلال العهد العثـاني أنواع عديدة من الحيوانات الأليفة التي كانت تسمى في ذلك العهد ( الحيوانات الأهلية ) ، وتشمل الأغنام والماعز والأبقار والجاموس والجمال ، فضلا عن الحيوانات التي كانت تستخدم في أعمال الزراعة والنقل كالخيول والبغال والحمير • وكانت

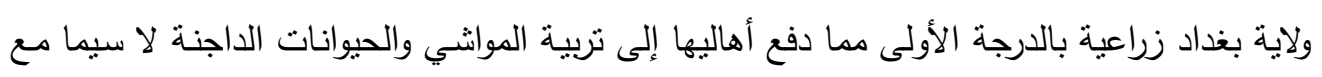
توفر الظروف الملائمة لتربيتها ـ وقد شكلت المنتجات الحيوانية النصف الثاني من الإنتاج الزراعي في الولاية ، ولم تقتصر أهمية المنتجات الحيوانية على قيمتها الغذائية فقط ، بل تعدتها إلى اعتماد أهالي الولاية عليها في مجالات أخرى .

لذا جاء اختيار البحث لبيان الأهمية المالية والاقتصادية والخدمية للثروة الحيوانية في ولاية

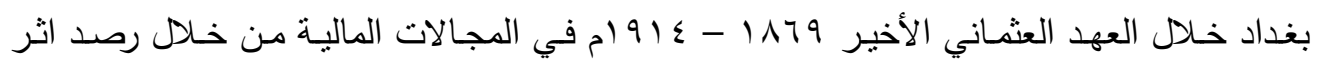
الثروة الحيوانية في ميزانية ولايـة بغداد ، وتوضيح أهميتها المالية خارج الموازنة من خلال الإيرادات

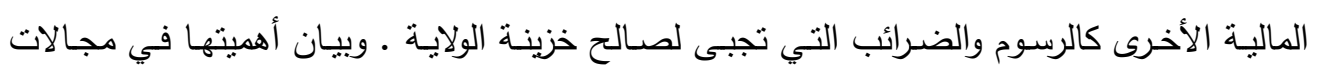
الصناعة سيما وأن بعض الصـناعات اعتمدت بالدرجة الأسـاس على المنتجات الحيوانيـة كالجلود والأصواف ، كما كان للمنتجات الحيوانية مساهمة واسعة في تجارة ولاية بغداد الخارجية ، واستخدمت باتهات الحيوانات كوسـائل نقل للمسافرين والبضـائع التجاريـة ، وسلط البحث الضوء أهميتها في الاستخدام العسكري والخدمات البريدية في ولاية بغداد . 
العـــــــد الثاني والعشرون

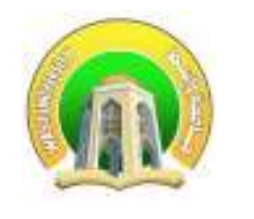

\section{مجلــــة كليـــــة التربيــــة}

أولاً : التوزيع الجغرافي للثرة الحيوانية في ولاية بغداد .

تتوعت الثروة الحيوانية في ولاية بغداد أواخر العهد العثماني ، سواء ما يربى منها للاستفادة من منتجاته المختلفة ، أو لمساعدة الفلاحين في أعمال الزراعة والنقل ، وقد قدرت الثروة الحيوانية

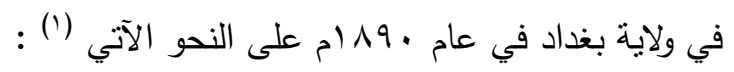

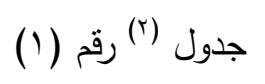

تقدير لأعداد الثروة الحيوانية في ولاية بغداد عام • 19 ام

\begin{tabular}{|c|c|c|c|c|}
\hline المجموع / رأس & لواء كربلاء & لواء الحلة & لواء بغداد & النوع \\
\hline$r 1 \ldots$. & $v \ldots \ldots$ & $v \varepsilon \ldots$ & $77 \ldots$ & الأغنام \\
\hline$\varepsilon \ldots$ & $1 \leq \varepsilon$. & 107. & $1 \ldots$ & الماعز \\
\hline $100 \ldots$ & or... & $7 \ldots$ & $\varepsilon r \ldots$ & الأبقار \\
\hline$\wedge \ldots$ & r.... & r.... & $r \ldots$ & الجاموس \\
\hline $90 \ldots$ & $r \leq \ldots$ & ro... & $\varepsilon \neg \ldots$ & الجمال \\
\hline$\wedge 0 \ldots$ & ro... & $r r \ldots$ & ґ.... & الخيول \\
\hline $1 \ldots$ & ro... & $\varepsilon \ldots$ & ro... & الحمير \\
\hline$\varepsilon \ldots$ & 177. & Tा. & $1 \ldots$ & البغال \\
\hline rצr.... & $1091 \ldots$ & $9199 \ldots$ & $\wedge \leq \varepsilon \ldots$ & المجموع \\
\hline
\end{tabular}

ويلاحظ من الجدول أعلاه أن الأغنام كانت الحيوانات الأكثر عدداً مقارنة مع الحيوانات

الأخرى في الولاية ، لذلك ستوزع حسب التقبيمات الإدارية لولاية بغداد وعلى النحو الآتي (r) : 
العـــــــد الثاني والعشرون

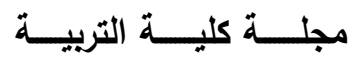

\section{جدول رقم (r) (}

أعداد الأغنام في أقضية ولاية بغداد عام • 9 ام

\begin{tabular}{|c|c|c|c|c|c|}
\hline العدد & القضاء & اللواء & العدد & القضاء & اللواء \\
\hline$r \ldots$. & الحلة & \multirow[t]{4}{*}{ الحلة } & $10 \ldots$ & بغداد & \multirow[t]{11}{*}{ بغداد } \\
\hline$r q \ldots$. & الديوانية & & $10 \ldots$ & ( دراسان & \\
\hline $1 \leq \ldots$ & الثامية & & $v_{\ldots} \ldots$ & العزيزية & \\
\hline $1 \leq \ldots$ & السماوة & & $7 \ldots$ & خانقين & \\
\hline ro.... & كربلاء & \multirow[t]{4}{*}{ كربلاء } & $0 \ldots$ & مندلي & \\
\hline ro.... & الهندية & & $\varepsilon \ldots$ & سامراء & \\
\hline $1 \ldots$ & النجف & & $\varepsilon \ldots$ & ( الصزيرة & \\
\hline $1 \ldots$ & الرزازة & & $90 \ldots$ & الدليم & \\
\hline \multirow[t]{3}{*}{$r_{1} \ldots$} & \multirow{3}{*}{\multicolumn{2}{|c|}{ المجموع الكلي }} & $9 \ldots$ & كوت الإمارة & \\
\hline & & & ro... & الكاظمية & \\
\hline & & & $9 \ldots$ & عانة & \\
\hline
\end{tabular}

ومن الجدير بالذكر أن الولايات العثمانيـة في العراق كانت من أهم الولايات الغنية بالثروة

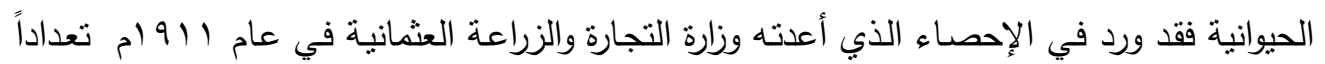
للحيوانات في ولايات العراق وعلى النحو الآتي (ء) : 


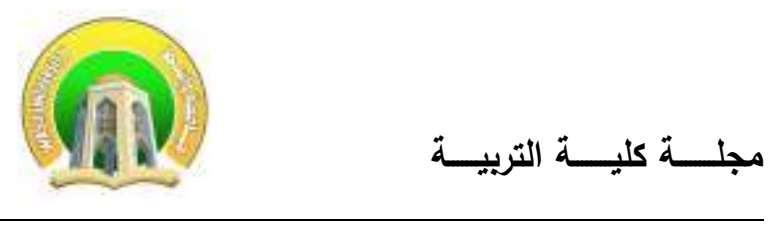

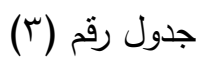

أعداد الحيوانات في ولايات العراق عام ا19 ام

\begin{tabular}{|c|c|c|c|}
\hline الموصل & البصرة & بغداد & النوع \\
\hline |N|AYT| & VAq. qr & هس" & الأغنام \\
\hline รา79ห7 & ro... & AVYIO & الماعز \\
\hline qrrی. & $1 \leqslant 9 r \circ 9$ & r YA & الأبقار \\
\hline $1 \leq \ldots 1$ & & ryor & الجاموس \\
\hline $9 \leq \ldots$ & rrqA. & YAYIY & الجمال \\
\hline & YIVVI & IV.Ar & الخيول \\
\hline rrv.. & 10 & $191 \mathrm{~V}$ & البغال \\
\hline $0.9 \ldots$ & $79 V 1 V$ & rוTי & الحمير \\
\hline- & $1.171 \ldots$ & rᄉ.0.. & الدواجن \\
\hline rV1017. & YIrVT & $9 \leq 7) \leq 1$ & المجموع \\
\hline
\end{tabular}

وفي مقارنة بين الجدولين السابقين رقم ( () و (r) يلاحظ انخفاضٌ كبيرُ في أعداد الحيوانات في ولايـة بغداد وذلك وهذا لانتشار الأمراض والأوبئة التي أصسابت الحيوانات في المناطق المختلفة

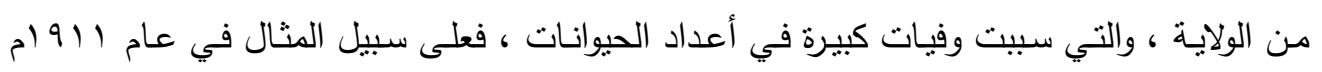

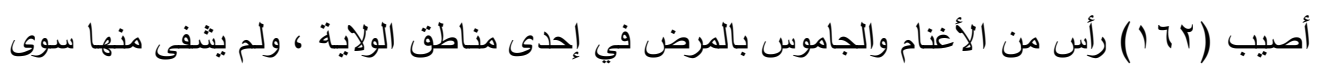
(97) رأس ، وبذلك فأن أكثر الحيوانات المصابة يكون مصبرها النفوق • ومن الأسباب الأخرى لقلة

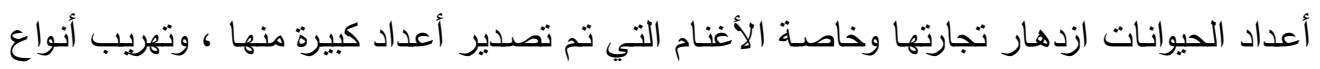

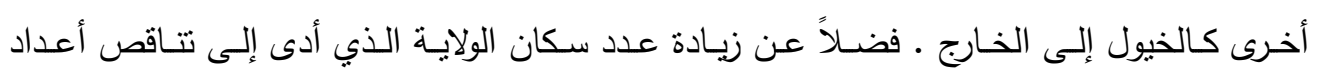

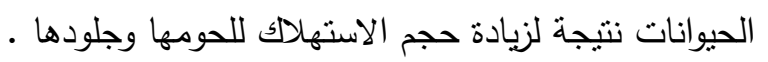




\section{العـــــــد الثاني والعشرون}

ويمكن إضـافة سبب آخر لتتاقص أعداد الثروة الحيوانيـة في ولايـة بغداد إلا وهو امتتاع

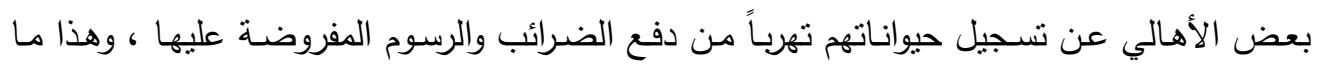

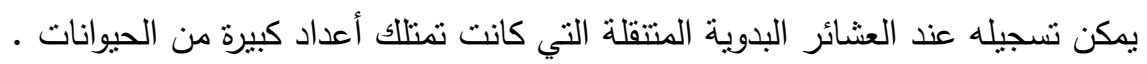

ثانياً : الإجراءات الحكومية العثمانية في فرض الرسوم على الحيوانات وجبايتها .

1- تثـكيل دائـرة ( نظـارة ) الأعشـار والأغنـام : أصدرت الدولـة العثمانيـة في 17 كانون الثاني

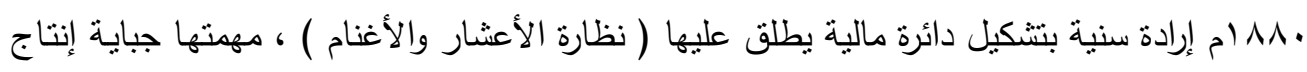

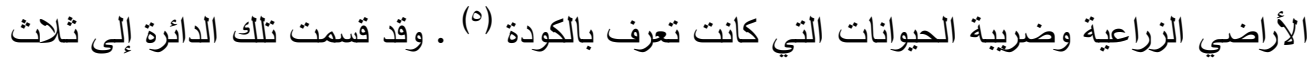

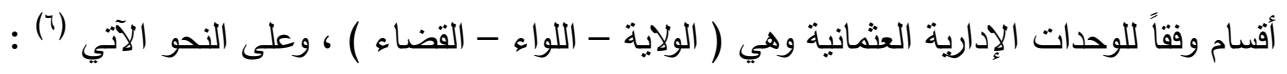
أ- في مركز الولاية : برئاسة الناظر ، وعضوية رئيس الكتّاب وثنلات معاونين ، وكاتب تحريرات ،

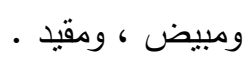
ب- في اللواء : برئاسة مدير ، وعضوية كاتب أول وثاني وثالث ، ومحصل . ت- في القضاء : برئاسة مأمور ( موظف ) ، وعضوية كاتب أول وثناني ، ومحصل . وكان الهيكل الإداري لهذه الدائرة في مركز ولاية بغداد يضم الناظر محمد أفندي ، ورئيس

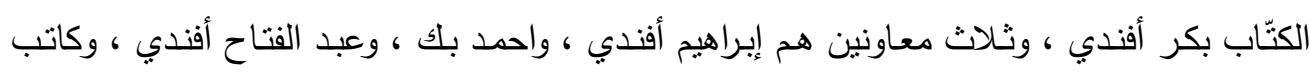

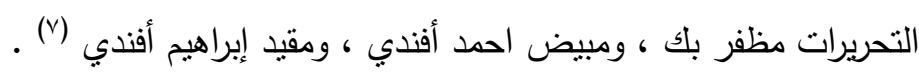
وقد ألغيت دائرة الإعشار والأغنام عام .1199 ، وذلك لقيام دوائر المحاسبة في مركز

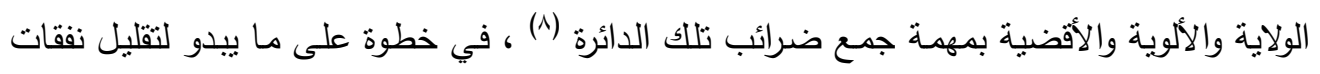
الولاية المالية .

ץ- آليـة جبايـة الرسـوم : مـن اجل نتظيم فرض الرسوم على الحيوانـات قسدت الدولـة العثمانيـة

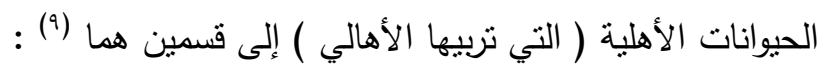




\section{العـــــــد الثاني والعشرون}

أ- الحيوانات التي يدفع عنها الرسوم وهي الأغنام ، والماعز ، والجاموس ، والجمال ، كونها تستقيد

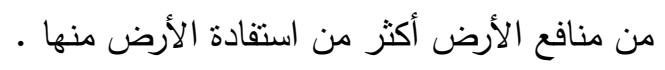

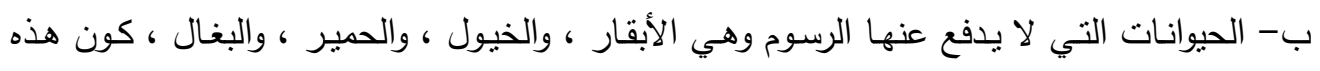

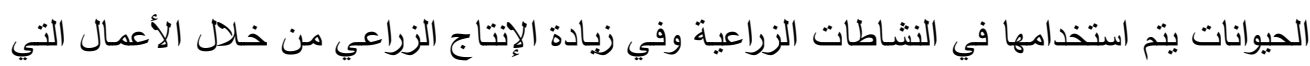
يمكن للفلاح أن يقوم بها بمساعدة نلك الحيوانات .

اهتمت الدولة العثمانية منذ أواخر القرن التاسع عثر للميلاد بجباية رسوم الحيوانات لما

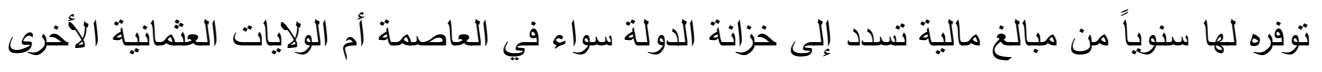

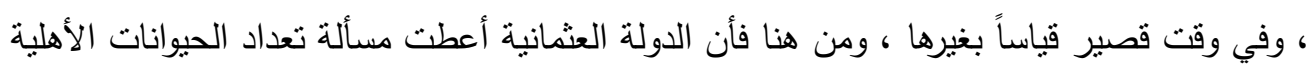

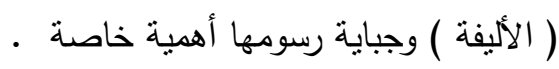

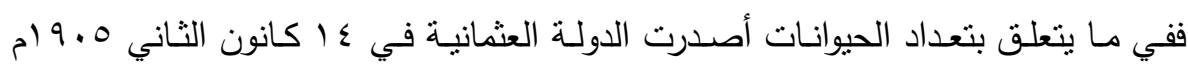

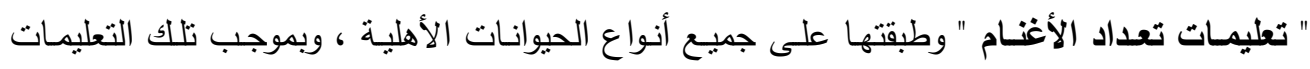

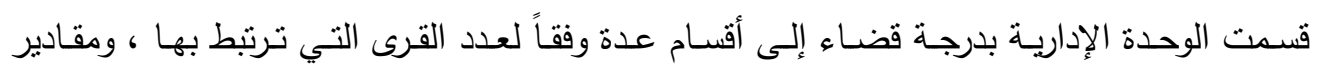

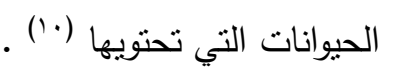

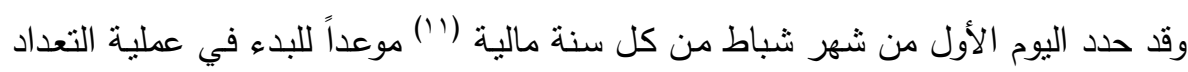

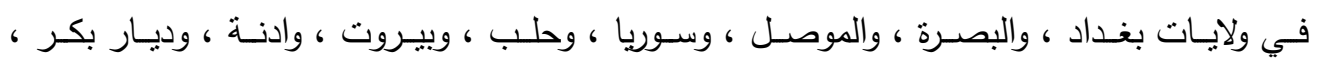

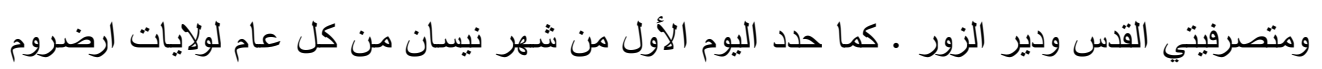

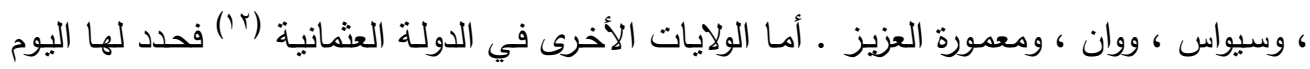

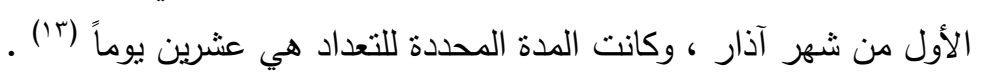

ووفقاً لتلك التعليمات كان على مختاري القرى وأعضاء الهيئة الاختبارية أن ينظموا نسختان

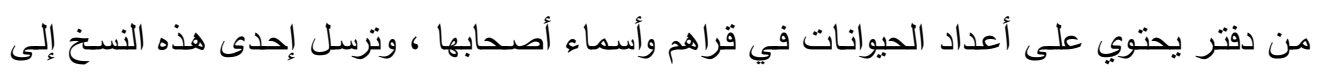

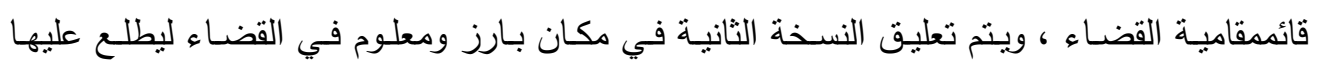




\section{العـــــــد الثاني والعشرون}

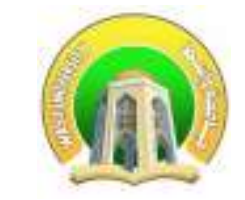

\section{مجلـــة كليــة التريبــة}

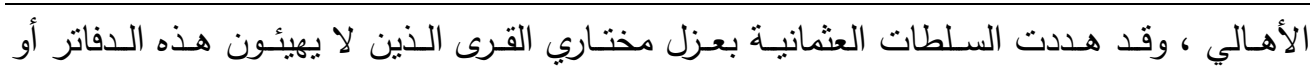

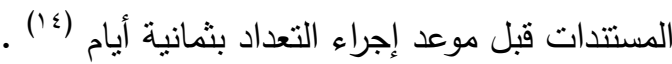

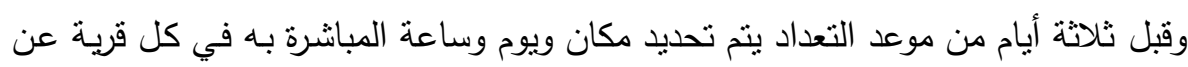

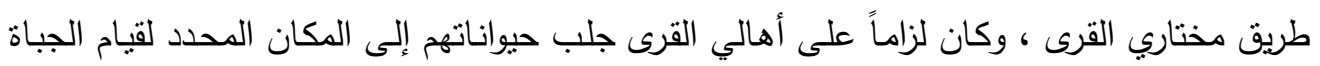

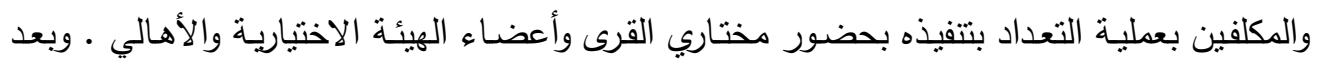

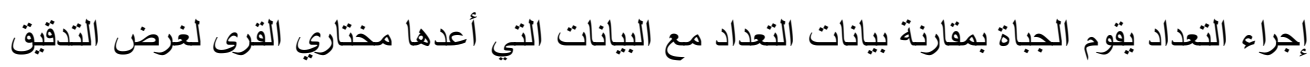

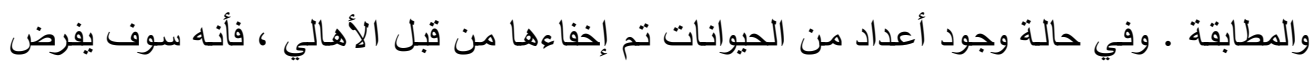

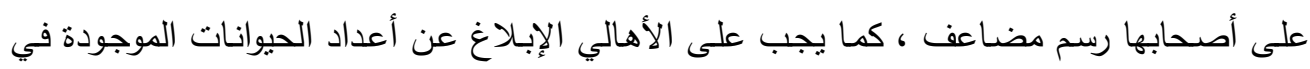

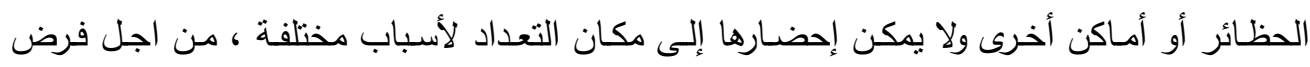
الرسوم عليها (10) - (10)

وبعد الانتهاء مـن تتظيم دفـاتر تعداد اللواء والاقضية المرتبطـة بـه ، ينظم جدول وفقاً

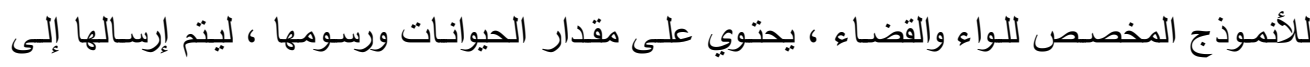

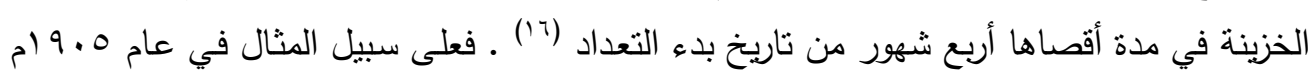

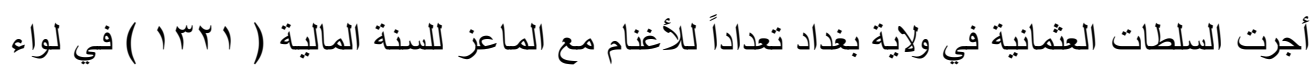

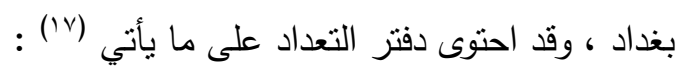


جدول رقم (乏)

أعداد الأغنام في لواء بغداد عام 0 (9

\begin{tabular}{|c|c|c|c|}
\hline عدد / رأس & القضاء & 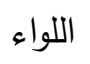 & السنة المالية \\
\hline ויצזי & بغداد & \multirow[t]{4}{*}{ بغداد } & \multirow[t]{4}{*}{ | } \\
\hline $1 \leq 0.07$ & خراسان & & \\
\hline $7 \leqslant 071$ & خانقين & & \\
\hline TVAฯ & مندلي & & \\
\hline$\varepsilon \leq \varepsilon \wedge \varepsilon$ & كوت الإمارة & & \\
\hline rצr & بدرة & & \\
\hline rT.01 & سامراء & & \\
\hline rATV & الكاظمية & & \\
\hline ATIKr & 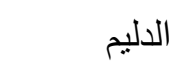 & & \\
\hline$r V \cdot V$. & العزبزية & & \\
\hline$r \cdot 1 \cdot r$ & الجزيرة & & \\
\hline OTOY. r & & & المجموع \\
\hline
\end{tabular}

أما بشأن جباية الرسوم وتحصليها فكان على كل مجالس الإدارة في الاقضية تعيين عدد

مناسب من الجباة المشـاة والخيالة قبل وصسول موعد إجراء التعداد ، وتعيين مفتشين لمراقبـة عمليـة تعداد الحيوانات في أوقات غير محددة ، كما يتم تكليف قائمقام القضاء بمهمة مراقبة عمل الجباة

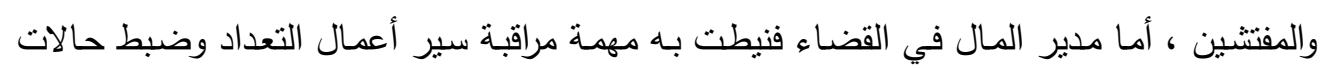
المخالفات أو التأخر التي قد تحدث (^^) ـ وكان موظفو تعداد الأغنام في أقضية لواء بغداد في عام

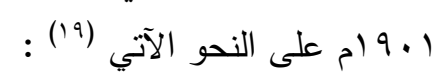




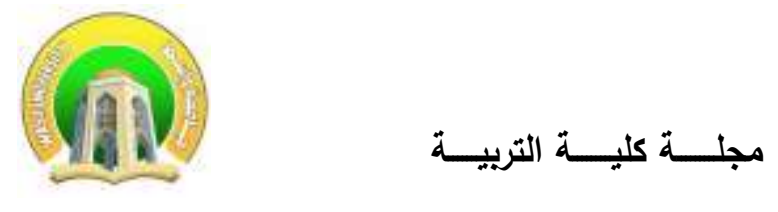

جدول رقم (0)

موظفو تعداد الأغنام في لواء بغداد عام 19 (م

\begin{tabular}{|c|c|}
\hline الموظف & القضاء \\
\hline احمد أفندي - مصطفى البكري & 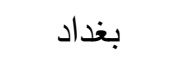 \\
\hline شوقي أفندي - عبد المجيد أغا - رشيد القايماقجي & خراسان \\
\hline عبد الرحمن آل مرجان & خانقين \\
\hline سيد شهاب أفندي - حسن الخضري & 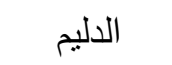 \\
\hline عبد الكريم أفندي - احمد الطاهر - محمد أمين جلبي الثيخلي & 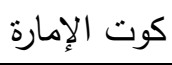 \\
\hline صالح آل مهدي - ميد آل احمد & 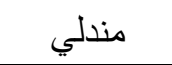 \\
\hline صالح أفندي - ميرزا أغا & 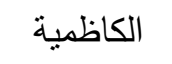 \\
\hline مرهج أغا & 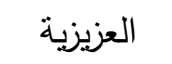 \\
\hline صالح آل عبد السلام & 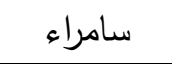 \\
\hline عبد العزيز أغا - عبد الغني الكروي & 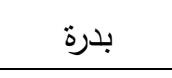 \\
\hline ملا صالح أفندي & عنه \\
\hline
\end{tabular}

كما أوعزت السلطات العثمانية في ولاية بغداد إلى متصرفي لوائي الديوانية وكربلاء بتعيين موظفي لتعداد الأغنام من جباة وكتّاب ، وتحديد المواقع أو الأماكن التي سوف يتم فيها إجراء التعداد

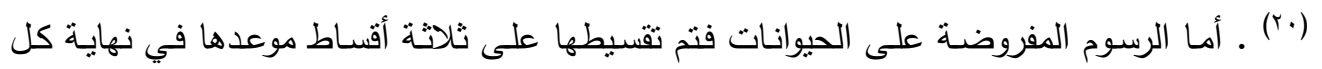
شهر من الثهور الثناثة ابتداءاً من بدء التعداد ، وفي حالة عدم تسديد أصحاب الحيوانات القسط المحدد عليهم ، فيتم إنذارهم بوجوب التسديد بعدها يتم استنفاء الرسوم من أثنان الحيوانات التي يتم بيعها في المزايدة العلنيـة ـ ومـن الجدير بالذكر أن مبالغ الرسوم التي تستوفى بواسطة الجباة يتن تسليمها إلى صناديق المـال مباشـرة وليس للقائمقامين أو مدراء النواحي أو مدراء المسال ، لضمان

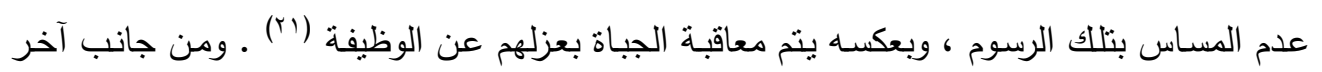




\section{العــــــدد الثاني والعشرون}

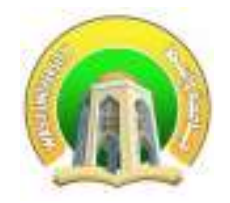

\section{مجلـــة كليــــة التربيـــة}

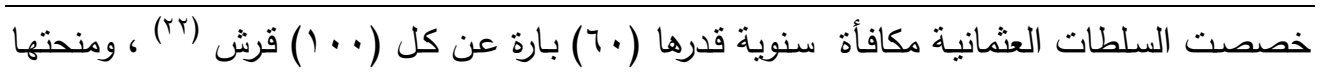
للقائمقام ومدير الناحية ومدير مال القضاء ، والمختار ومجلس اختياريـة القربة ، من اجل تحفيزهم للقيام بعملية التعداد على أكمل وجه (rr) .

ثالثاً : الأهمية المالية للثروة الحيوانية .

ا- رسوم الحيوانات : فرضت الدولة العثمانية رسوماً وضرائب على الحيوانات ( الأغنام والماعز ) ، وكانت هذه الرسوم تعرف في ولايات العراق الثناث باسم الكودة ، وقد اختلف مقدار تلك الرسوم من

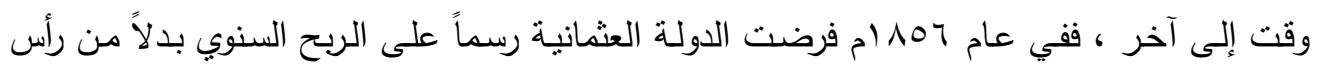
المال وتم تكليف المجالس الإدارية في الوحدات الإدارية المختلفة بتحديد التقديرات ، فتقرر فرض رسم مقداره (0، 1) قرش عن ثمن الإنتاج السنوي المقدر بـ (0 1) قرشاً (ع) . ـوقد أضيف إلى هذا الرسم

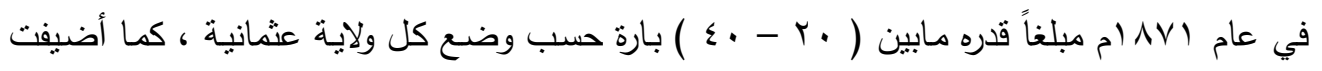

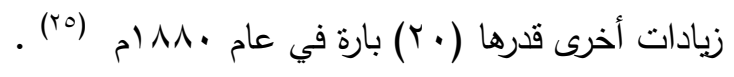

وفي عام 1^9 ام فرضت السلطات العثمانية رسوماً جديدة على الأغنام والماعز اختلفت

مقاديرها باختلاف الولايات التابعة للاولة وعلى النحو الآتي (بr) : 


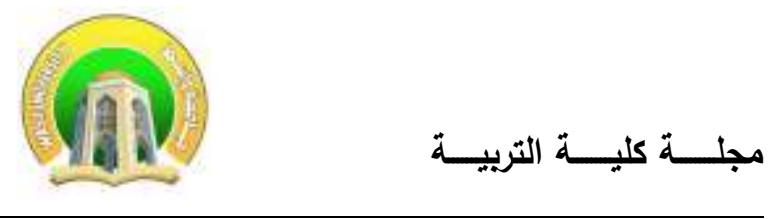

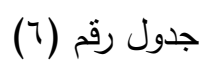

الرسوم المفروضة على الأغنام والماعز في الولايات العثمانية عام 1199 ام

\begin{tabular}{|c|c|c|}
\hline رأس الماعز / قرش & رأس الغنم / قرش & 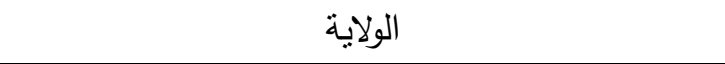 \\
\hline$\varepsilon, 0$ & r.0 & أنقرة ، ارضروم ، قسطموني ، وان ، بتليس ، ديار بكر \\
\hline$\varepsilon_{60}$ & $\varepsilon_{6} 0$ & أيدين ، خداوندكار \\
\hline$\varepsilon_{6} 0$ & r & الموصل - ال المل \\
\hline$\varepsilon, 0$ & r.o & سورية ، حلب ، معدورة العزيز \\
\hline$\varepsilon, 0$ & r & بغداد ، اشقودره \\
\hline$\varepsilon, 0$ & 0 & أدرنة ، سلانيك \\
\hline$\varepsilon, 0$ & 1 & 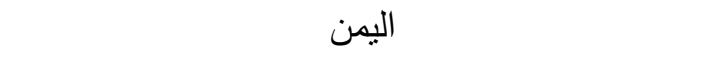 \\
\hline V & r.o & طرابزون \\
\hline$\varepsilon_{6} 0$ & $r_{6} 0$ & 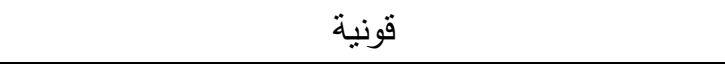 \\
\hline$\varepsilon_{6} 0$ & $0, r$ & 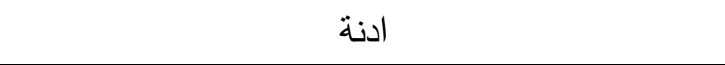 \\
\hline$\varepsilon_{6} 0$ & $\varepsilon_{6} 0$ & أمانة العاصمة ( إسطنبول ) \\
\hline$\varepsilon, 0$ & $r_{6} 0$ & متصرفية دير الزور ، متصرفية القدس \\
\hline
\end{tabular}

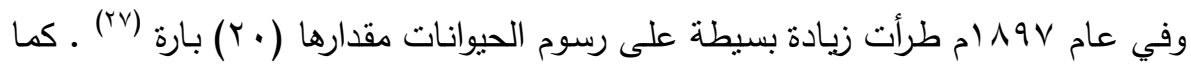

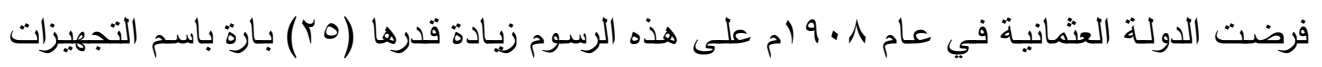
العسكرية للقوات العسكرية العثمانية ، ثم أضافت عليها في عام ب إو ام ( • ( ) بارة باسم الأسطول ( البحري العثماني ) لبصل مقدار رسم الأغنام في الولايات العربية ومنها ولاية بغداد ، أواخر العهد

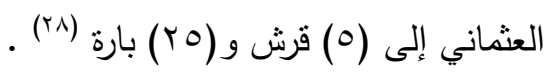




\section{العــــــد الثاني والعشرون}

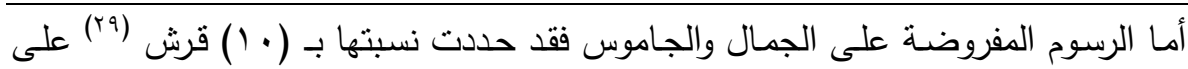

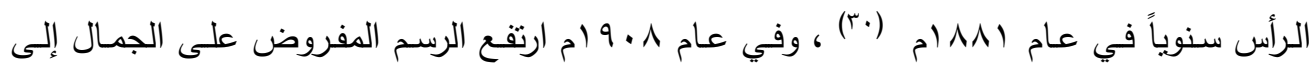

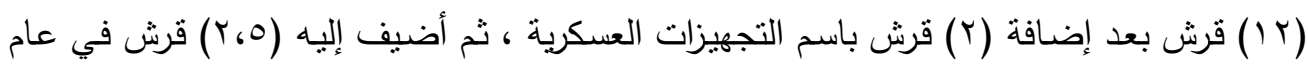

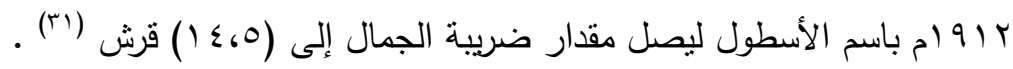

r - مساهمة الثروة الحيوانية في الموازنة المالية لولاية بغداد :

أ- أصول تنظيم الموازنة في الدولة العثمانية .

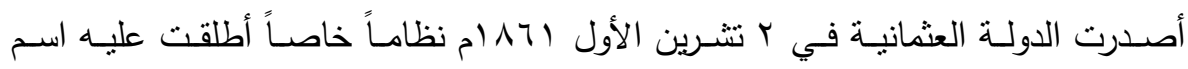

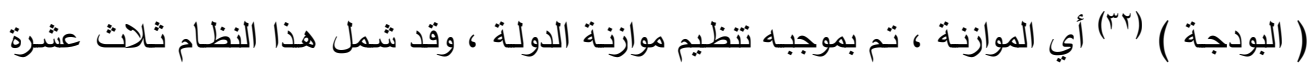

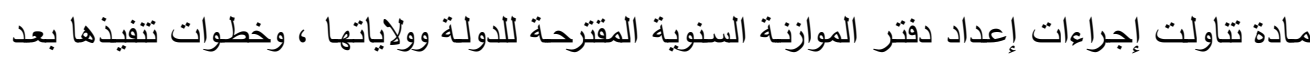

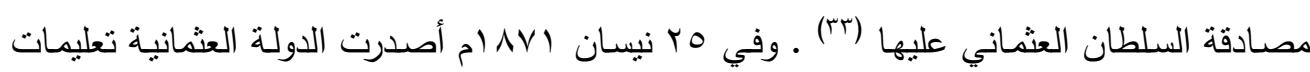

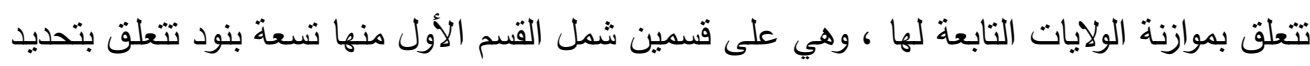

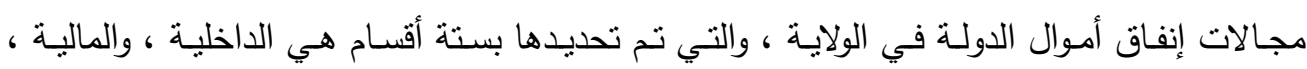

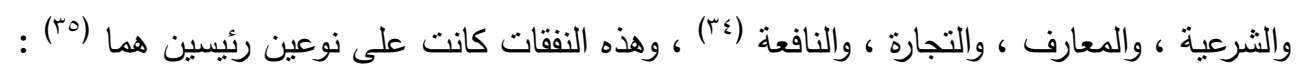
1- النققات الدحددة : وتشمل الرواتب والأجور والبدلات المقطوعة للاوائر التي تصرف مخصصاتها في دوائرها .

r- النفقات غير المحدة : وقد حددت لها مبالغ معينة لا يمكن تجاوزها وهي على ثلاثة أنواع : أ- أثمان التركات والأموال المعادة إلى أصحابها بعد ثبوت ملكيتهم لها ـ ب- النفقات الاعنيادية : وتتشل تعيينات جهاز الثرطة ( الضبطية ) ، ونفقات الغذاء والعلاج والنقل

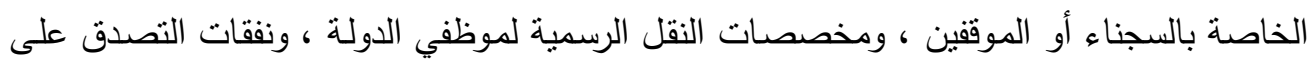

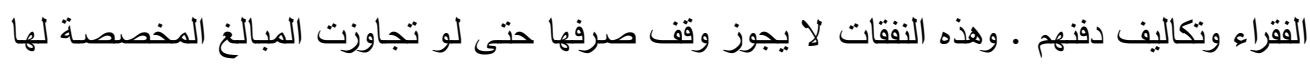

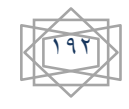




\section{العــــــد الثاني والعشرون}

إذ يتت تحويل مبالغ إضـافية لها من واردات أعشار الخزينـة بعد إبـلاغ خزينـة الدولـة المركزيـة في

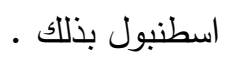

ت- النفقات المخصصة لبناء مراكز الثرطة والثأثثث والملابس والمحروقات والإيجارات المتعلقة بها

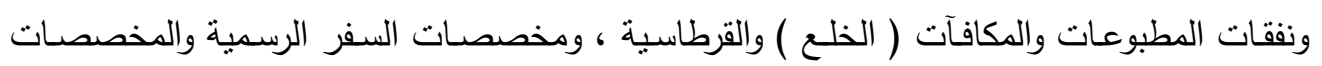

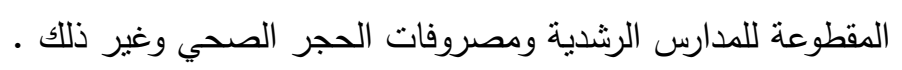

في حين تتاول القسم الثاني تتظيم دفتر موازنة الولاية ، وضم عشرة بنود أوضحت أسلوب ترتيب الموارد والنفقات العامة في ذلك الدفتر (جنَ) .

كانت الدولة العثمانية قبل صدور نظام البودجة عام الیام وتعليمات موازنة الولايات لعام ملر AV

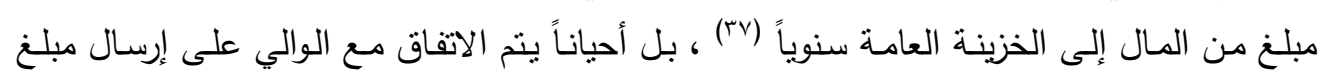

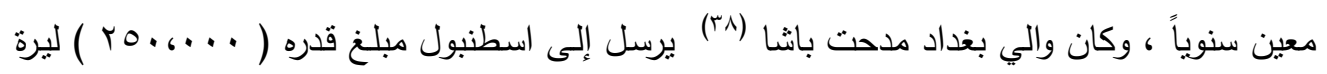

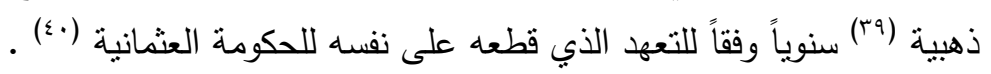

ومن اجل تفادي الضغوط التي تفرضها الحكومـة العثمانية على والي بغداد مدحت باثـا

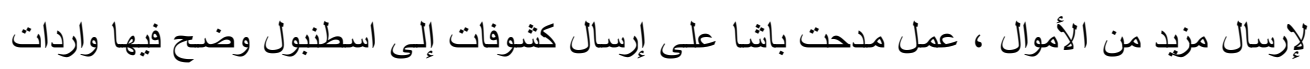
ونفقات ولايته (1) من الإندال

r- رسوم الحيوانات احد أبواب إيرادات موازنة الولاية المالية : أ- إيرادات الموازنة المالية من رسوم الحيوانات .

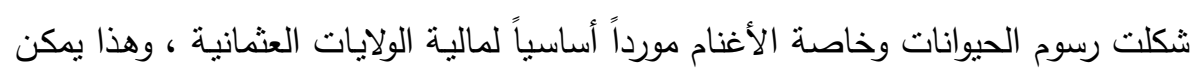

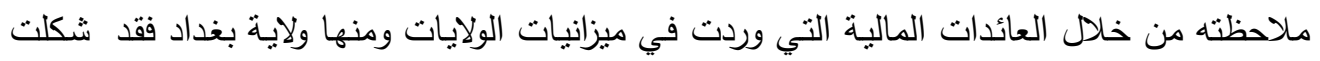

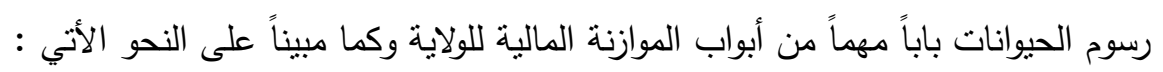

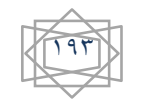


العـــــــد الثاني والعشرون

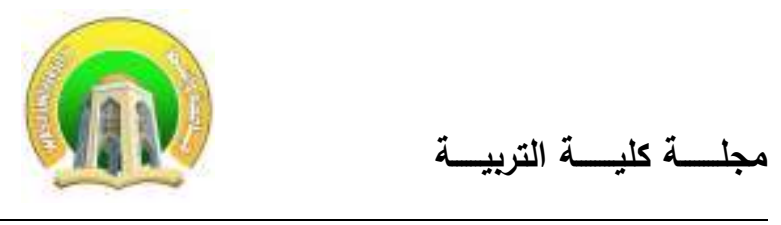

جدول رقم (V)

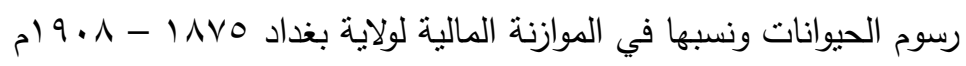

\begin{tabular}{|c|c|c|c|c|}
\hline النسبة & إيرادات الموازنة & رسوم الحيوانات & والميلادية & السنة المالية \\
\hline \%) • & $T \leq \Lambda \leq O V T T$ & 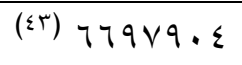 & $1 \wedge V T-V 0$ & $(\varepsilon r), Y q \mid$ \\
\hline$\% 19.9 \leq$ & $r \leqslant 7 r \cdot r \circ q$ & ¿qा roV. & $1 \wedge \wedge 0-\Lambda \varepsilon$ & («\&) , \\
\hline$\% 1964 \wedge$ & rrq.$v 19$ & 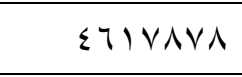 & $1 \wedge \wedge 7-\wedge_{0}$ & $(\leqslant 0), T .1$ \\
\hline$\%$ \% & TrTEYYIT & $T r \Lambda \cdot r \cdot O$ & $11997-90$ & 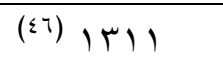 \\
\hline$\% 17 . V$. & YN $50 V 10$. & $\leqslant V 0 \leqslant \leqslant Y_{0}$ & $11999-91$ & $(\varepsilon V)|M| \varepsilon$ \\
\hline$\% 19610$ & $r q \varepsilon \cdot V T \cdot \varepsilon$ & $0.0 \vee \wedge \leqslant 7$ & $19 \ldots-99$ & (纟八) \\
\hline$\% \backslash A_{6} Y \leq$ & YTOTIYAE & $\varepsilon \wedge \varepsilon 17 \vee V$ & $19.1-\ldots$ & (ะq) \\
\hline$\% 17.9$. & rrq.rוrr & TAVTTYK & $19 . r-.1$ & (0.) \\
\hline \%) & . & 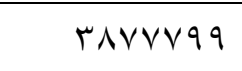 & $19 . \varepsilon-. r$ & (01) 11719 \\
\hline$\% 10,1$. & $r r V \leq \leqslant 90 \leqslant$ & TONVTM & $19.7-.0$ & וTו IT) \\
\hline$\%) \leq 6 . \leq$ & rrro.... & rrtoo.. & $19.8-.7$ & (OT) ITYK \\
\hline$\% 10.79$ & $r \varepsilon . \wedge r \ldots$ & rVA.0.. & $19.1-. V$ & אזrו (ס) \\
\hline
\end{tabular}

ب - إيرادات الحيوانات ونسبها مقارنة بموازنة الدولة العثمانية المركزية :

لقد شكلت رسوم الحيوانـات في ولايـة بغداد مورداً ماليـاً مهمـاً في الموازنـة الماليـة للولايـة وكانت نتكل نسبة وصلت في بعض السنوات إلى حوالي (rv) من الإيرادات المالية كما في عام 11990 - 197 (م ، وكانت الإيرادات الماليـة المتحققة من رسوم الحيوانات في موازنـة ولايـة بغداد تشكل نسبة حوالي (ع، r \% ) من مجموع الإيرادات المالية المتحققة من رسوم الأغنام في الموازنـة المالية المركزية في الدولة العثمانية ، وكما مبين على النحو الآتي : 
العــــــدد الثاني والعشرون

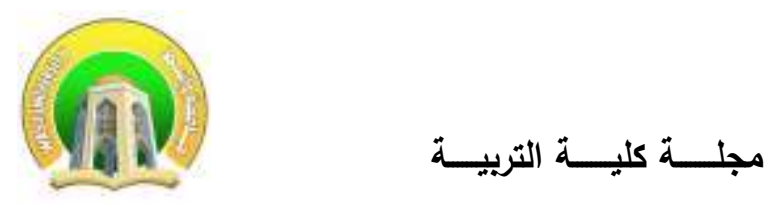

جدول رقم (^)

إيرادات الحيوانات في ولاية بغداد ونسبها مقارنة بموازنة الدولة المركزية في اسطنبول

م) $9 \cdot \Lambda-1 \Lambda V$.

\begin{tabular}{|c|c|c|c|c|}
\hline 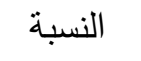 & رسوم الحيوانات في الدولة & رسوم الحيوانات في & \multicolumn{2}{|c|}{ السنة المالية والميلادية } \\
\hline \%r.r. & (oג) וтrqr।... & (0v) po909.. & $|\Lambda V|-V$ & (07) I YAT \\
\hline$\% 1.9 \leq$ & $r \cdot r) 9 \leq 0 .$. & (7.) & $|\Lambda V T-V|$ & $(09)$ I TAV \\
\hline \% & $r .0190 \ldots$ & $779 \vee 9 . \varepsilon$ & $1 \wedge V_{T}-V_{0}$ & $|r q|$ \\
\hline$\%$ r.vo & iv100r... & ¿qा roV. & $1 \wedge \wedge 0-\wedge \varepsilon$ & . \\
\hline$\% r_{6} r_{4}$ & r) rNOrr & $\varepsilon V 0 \leqslant \leqslant Y_{0}$ & $1199-91$ & ع \\
\hline$\% r_{6} \varepsilon r$ & r. NVqOVY. & $0.0 \vee \wedge \varepsilon 7$ & $19 \ldots-99$ & 1M10 \\
\hline \% & r. KAтTr०q & $\varepsilon \wedge \varepsilon \mid T \vee V$ & $19.1-\ldots$ & 4וTו \\
\hline$\% 1.90$ & |9NT1. TAr & TAVYTrY & $19 . r-.1$ & IVIV \\
\hline$\% 1.97$ & $19 V 1 T \cdot A \leq r$ & rAvVVqq & $19 . \varepsilon-. r$ & (7) \\
\hline$\%$ \% ،八 & $19 r 09401 \leq$ & TONVYTI & $19.7-.0$ & ITI \\
\hline$\%$ \% ،八V & $1 \vee \leq 71 \vee 770$ & rrq00.. & $19.8-.7$ & (TH \\
\hline$\% r_{6} \cdot r$ & $1 \wedge 7 . \leqslant 9 \cdot \leq 1$ & rv^.0.. & $19.1-. v$ & אזץו (זי) \\
\hline
\end{tabular}

ت- رسوم الأغنام المصدر الأساسي من بين رسوم الحيوانات في الموازنة المالية للولاية :

شكلت الأغنام العنصر الأساسي والأكثر أهمية في الثروة الحيوانية في ولاية بغداد ، بسبب

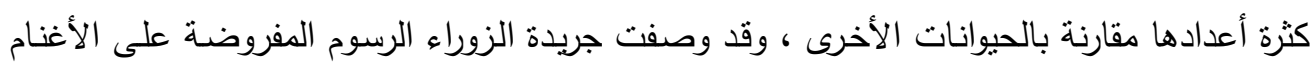

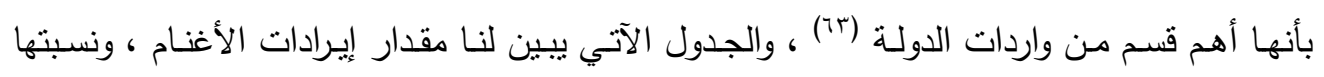

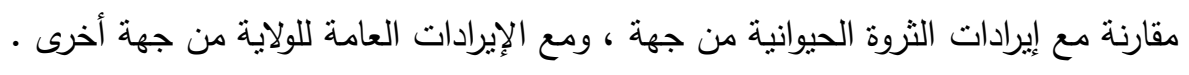


العــــــدد الثاني والعشرون

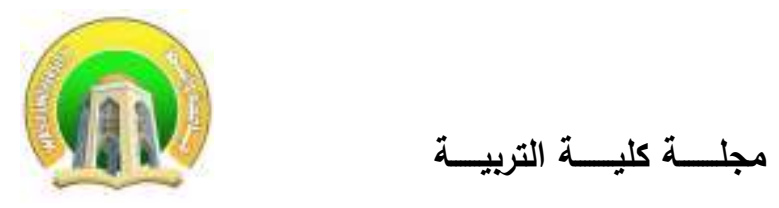

جدول رقم (9) (9) - (9)

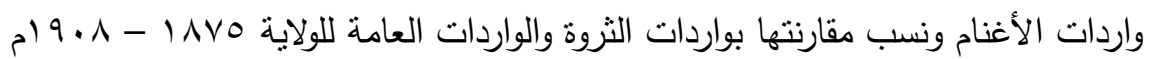

\begin{tabular}{|c|c|c|c|c|c|}
\hline النسبة & $\begin{array}{c}\text { إيرادات الولاية } \\
\text { العامة }\end{array}$ & النسبة & إيرادات الثروة & إيرادات الأغنام & السنة \\
\hline \% & $7 \leq \Lambda \leq O V T M$ & $\% 99.91$ & $779 \vee 9.5$ & $7797 \ldots$ & $|r q|$ \\
\hline$\%) V_{6} \wedge$. & $r \leqslant \neg r . r \circ q$ & $\% \wedge 9_{6} \wedge \wedge$ & ¿qा roV. & سน & ... \\
\hline$\% 17.79$ & rrqE.VIq & 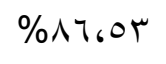 & 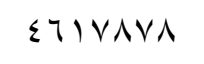 & ए997.7) & IT. \\
\hline$\% r \leq 6 \leq r$ & Tr|TYY & $\% 9 \cdot . \wedge \wedge$ & $T r \Lambda \cdot r \cdot O$ & ov.VqT० & וा \\
\hline$\% \mid 0,11$ & $r \wedge \leq 0 \vee 10$. & $\% 9 \cdot ، \wedge V$ & $\varepsilon V 0 \leqslant \leqslant Y_{0}$ & $\varepsilon r r . \varepsilon 1 \leqslant$ & ع| \\
\hline$\% 1 V_{6} .7$ & r & $\% \wedge 96.9$ & $0.0 \vee \wedge \leqslant 7$ & צ0. & ס \\
\hline$\% \backslash 7,1 \leq$ & YTOMIYAE & $\% \wedge \wedge_{6} \leqslant 9$ & $\varepsilon \wedge \varepsilon 17 \vee V$ & $\varepsilon r \wedge \Sigma \vee \wedge r$ & TוT \\
\hline$\% \backslash \leq 601$ & rrq.rוrr & $\% \wedge 0_{6} \wedge 7$ & TAVYTYY & TMOTEV & VוT \\
\hline$\% \backslash \leq 67 \mid$ & . & $\% \wedge V_{6} \wedge r$ & 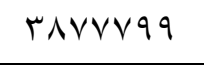 & $r \leq .0111$ & 1119 \\
\hline$\% 10,1$. & rrV $\leq \varepsilon q 0 \leq$ & $\% 1 \ldots$ & TONVYTI & TONVYTI & וז'ו \\
\hline$\%) \leq 6 . \leq$ & rro.... & $\% 1 \ldots$ & rroo.. & . & אYTM \\
\hline$\%) \leq 6 \leq 1$ & $r \varepsilon \cdot \wedge r \ldots$ & $\% 91, \wedge 1$ & rVA.0.. & $r \leq v 1 \ldots$ & TrT \\
\hline
\end{tabular}

رابعاً : الأهمية الاقتصادية للثروة الحيوانية .

لم تقتصر الفائدة المالية المتحققة من الثروة الحيوانية على الرسوم المفروضة على تربيتها ،

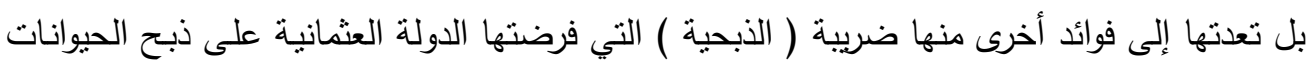

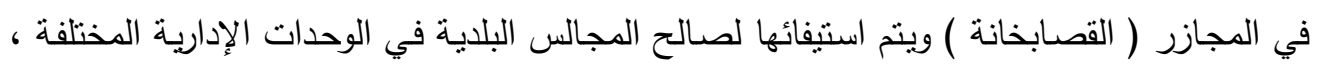

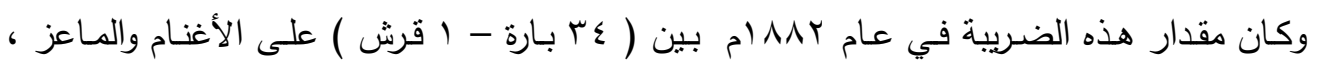

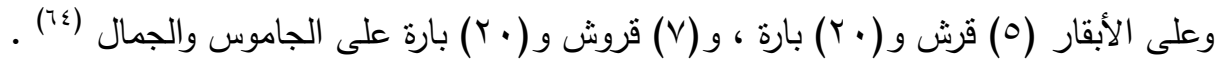


وقد ارتفعت هذه الضـريبة تـدريجياً ، إذ أصدرت الدولـة العثمانيـة في و ب كـانون الأول

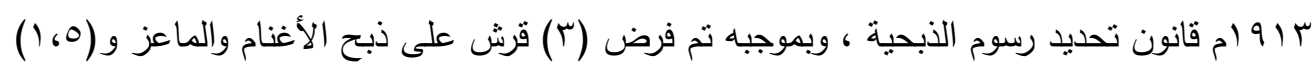

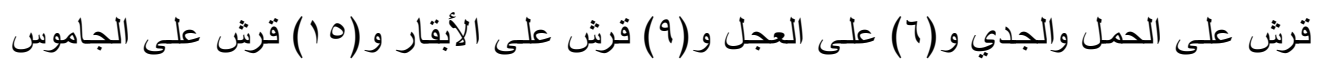
والجمال (70) . (10)

كما أن السلطات العثمانية كانت تستوفي بدل إيجار المجازر التي كانت تتبع دوائر البلدية

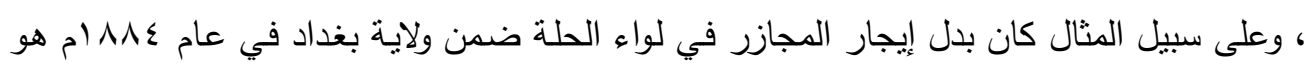

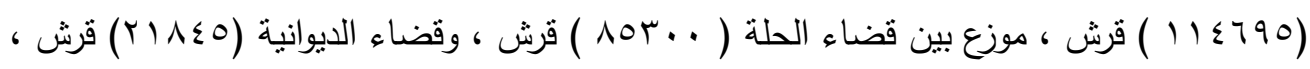

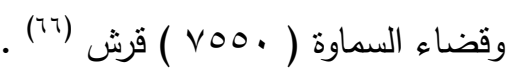

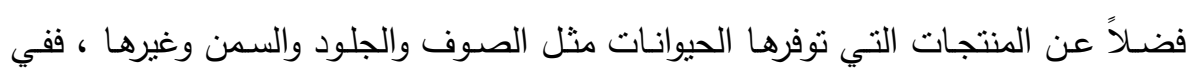

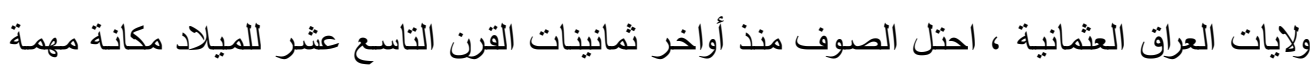

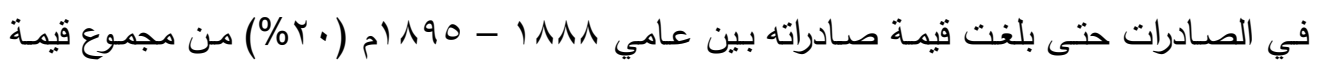

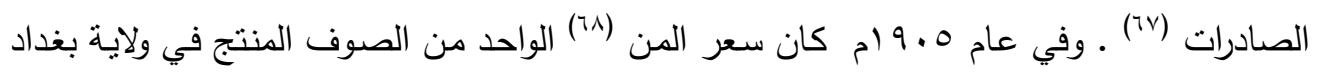

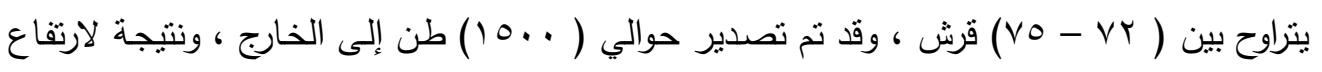

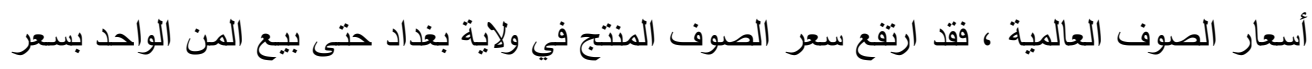

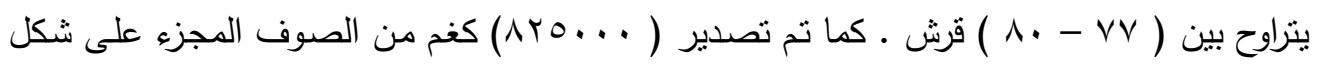

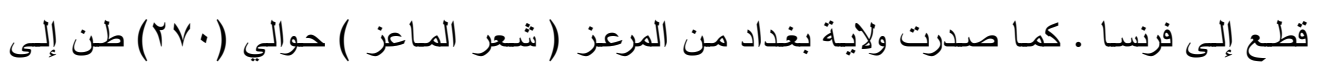

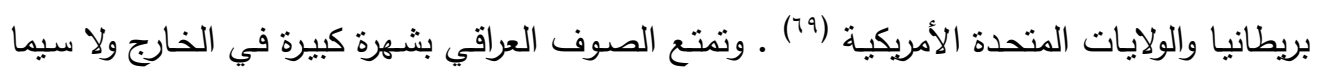

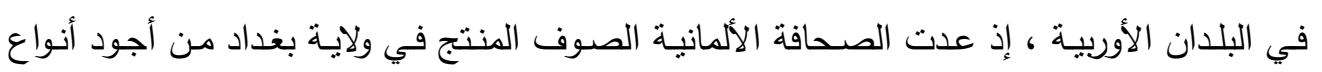

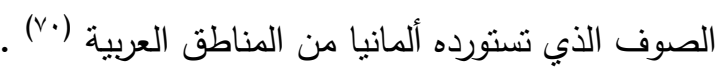

شملت صادرات الولايات العراقية كذلك الجلود بأنواعها المختلفة سواء كانت المدبوغة وغير

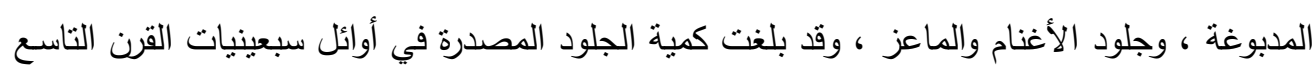

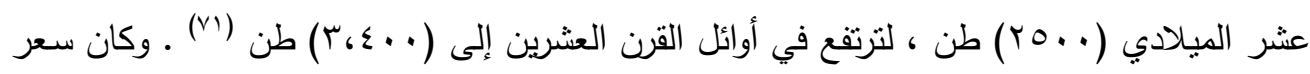

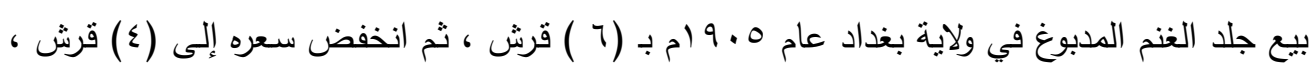

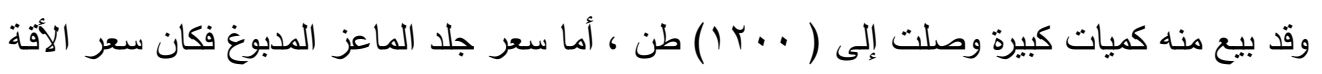

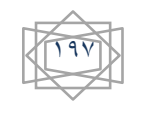




\section{العـــــــد الثاني والعشرون}

الاستانبولية (VY) (19) ) قرشاً ، ثم انخفض إلى (1) (1) قرش ، وتم تصدير كمبات إلى الخارج بلغت

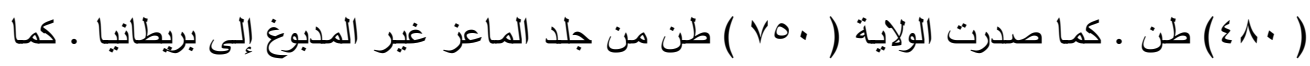

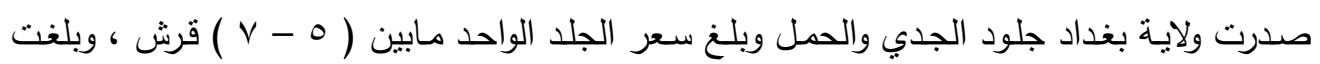

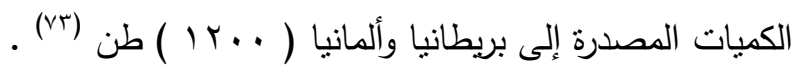

ومن المنتجات الحيوانية الأخرى السمن الحيواني ( الدهن ) الذي كان ينتج بكميات كبيرة

في ولاية بغداد ، وقد تراوح سعر الأقة الواحدة في بعض مناطق الولاية كبغداد والسماوة والهندية مابين

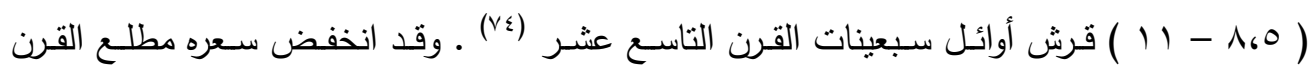

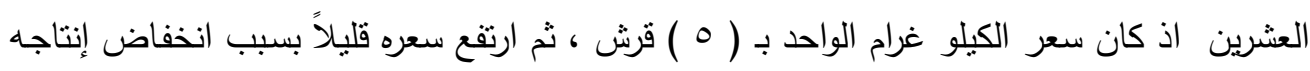

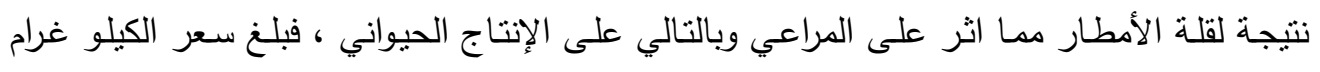

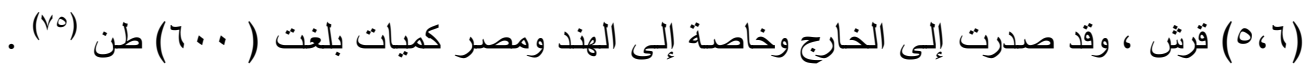

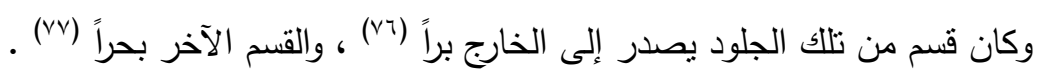

أمسا أحثـاء الأغنـام ( المصـارين ) فكان الطلب عليهـا كثبـراً مسن قبـل الولايـات المتحـدة

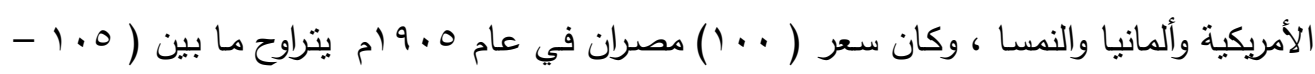

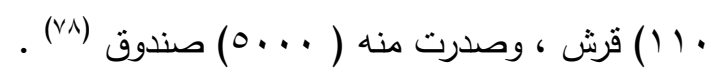

وكانت تجارة الحيوانات الحية تحقق إرباحاً مالية كبيرة وخاصة تجارة الخيل إذ قام التجار

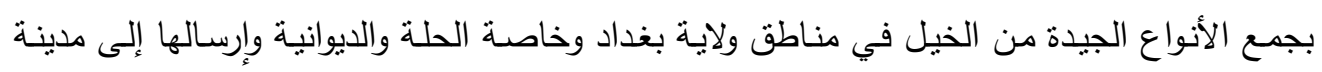

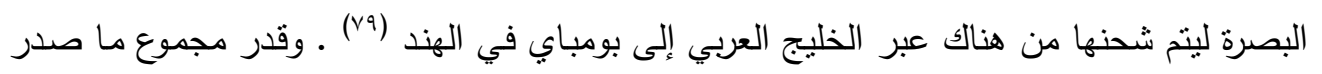

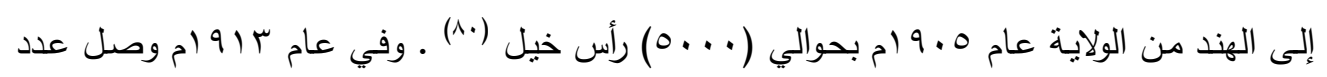

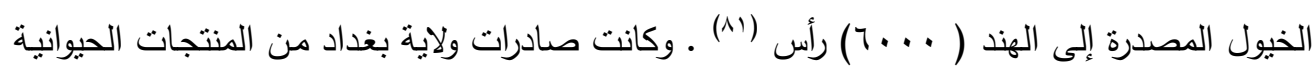

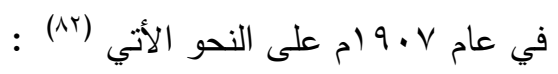




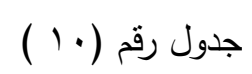

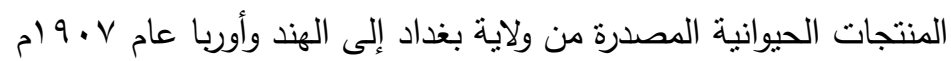

\begin{tabular}{|c|c|c|c|c|}
\hline \multicolumn{2}{|c|}{ 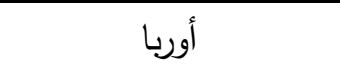 } & \multicolumn{2}{|l|}{ الهند } & \multirow[t]{2}{*}{ البضاعة } \\
\hline السعر / قرش & الكمية & السعر / قرش (r) & الكمية & \\
\hline OHNTH. & $|r q \wedge|$ & - & - & الجلود ( صندوق ) \\
\hline$\| r \leq 1 \leq 0$. & Tイ & ror. & 17 & الجلود ( بالة ) \\
\hline rrvч... & 411. & riva.. & r^q & الصوف ( بالة ) \\
\hline $1947 \ldots$ & $1 \cdots$ & - & - & شعر المرعز ( بالة ) \\
\hline |O^E.. & $7 \leq$ & - & - & السمن ( صندوق ) \\
\hline VYrA.. & rrq & - & - & الأحشاء المملحة ( صندوق ) \\
\hline rrqq.. & $\leqslant 1 \wedge$ & - & - & الروث ( قطع ) \\
\hline
\end{tabular}

وفي عـام 9 و9 ام حققت ولايـة بغداد إيـرادات ماليـة من المنتجات الحيوانيـة كانت على

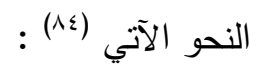

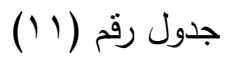

\begin{tabular}{|c|c|c|}
\hline ملاحظات & مقدار الواردات / بالقرش & 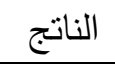 \\
\hline من الأغنام والأبقار والجاموس & $0 \leq V \cdot \varepsilon \cdot V$ & الحليب \\
\hline من الأغنام والأبقار والجاموس & $\vee \vee \vee \wedge V_{6} 0$ & 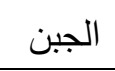 \\
\hline من الأغنام والأبقار والجاموس & מצr & 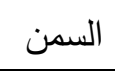 \\
\hline من الأغنام فقط & $11 \leq 97967$ & الصوف \\
\hline 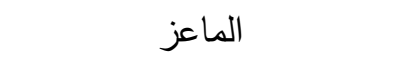 & IrAIV. & الثعر \\
\hline \multicolumn{2}{|c|}{$11 \leqslant \wedge 970 \vee, \varepsilon$} & 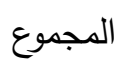 \\
\hline
\end{tabular}

واردات المنتجات الحيوانية في ولاية بغداد عام 9 ـ 9 (م 
العـــــــد الثاني والعشرون

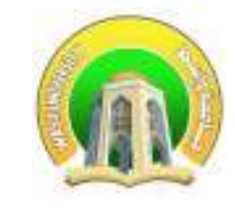

\section{مجلــــة كليـــــة التربيــــة}

وكانت أهم الدول المستوردة للمنتجات الحيوانية كالصوف والجلود بريطانيا وفرنسا والولايات المتحدة

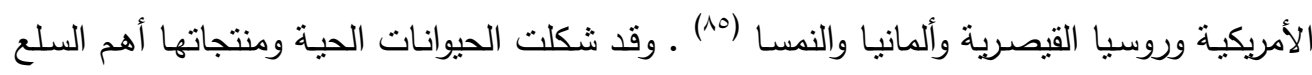
التجارية المصدرة من الولاية إلى الخارج وكما مبين في الجدول الآتي (†ث) :

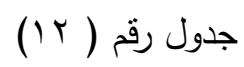

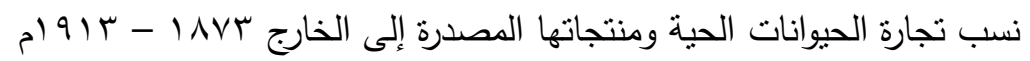

\begin{tabular}{|c|c|c|c|}
\hline الجلود & الصوف & الحيوانات الحية & السنة \\
\hline$\% \cdot .0$ & $\%$ \% & $\% r$ & p) $\wedge \vee q-1 \wedge V r$ \\
\hline$\% 1$ & $\%$ \%. & $\% \varepsilon$ & م)190-1111 \\
\hline$\%$ & $\% 17$ & $\% 1$ & 2) $9.1-1197$ \\
\hline$\%$ & \%וr & \%r & 21911-19.5 \\
\hline$\%$ & $\% 9$ & $\%$ & $2191 r-191 r$ \\
\hline
\end{tabular}

وفيما يتعلق بالصناعات التي اعتمدت المنتجات الحيوانية فهي صناعة الجلود التي انتشرت

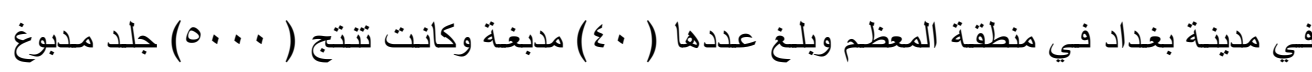
أسبوعياً ، كما وجدت مدابغ في الكاظميـة ـ ومـن الصناعات التي اعتمدت على الجلود صناعة الأحذية الرجالية والنسائية والتي انتشرت في مدينة بغداد (Nv) ، وصناعة السروج والأحزمة والنصول والبراذع (^^) . وكان في بغداد مكبسين للصوف ، وهو من المواد الخام الرئيسة في صناعة بعض الأقمشة والعباءات والخيام (^9) . 
خامساً : الأهمية الخدمية للثروة الحيوانية .

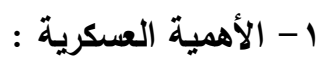

كان للخيول والبغال أهية كبيرة من الناحية العسكرية فهي كانت تستخدم من قبل خيالة

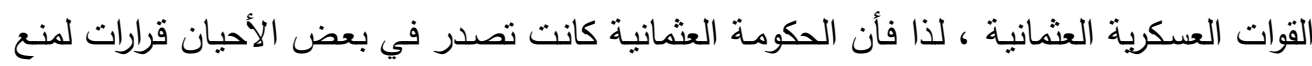

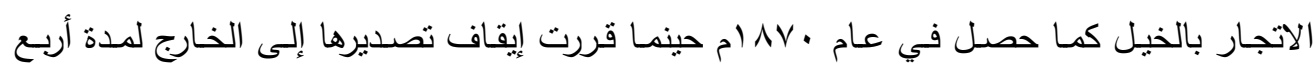

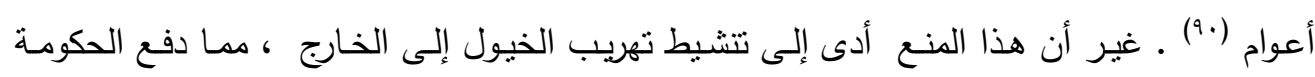

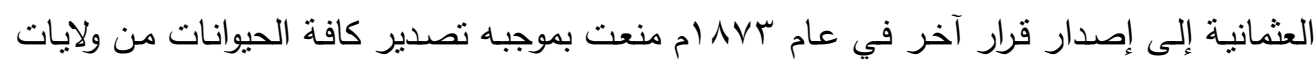

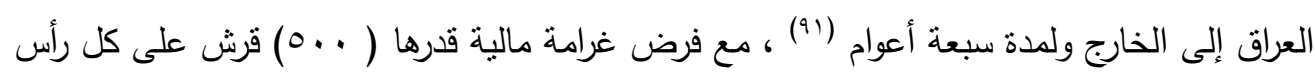

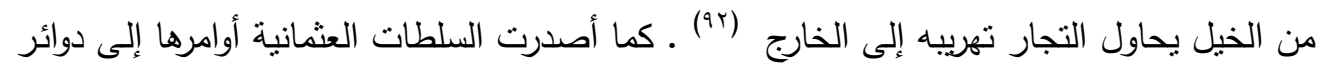

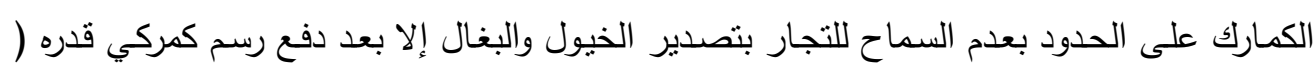

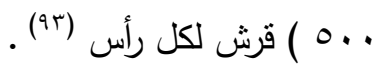

كما شكلت الدولة العثمانية في أواخر عام 991 ام قوه عسكرية سميت بـ ( كتيبة البّغالة ) على غرار كتائب الخيالة ، وقد ارتبطت تلك الكتيبة بقوات الضبطية في ولاية بغداد ، وجاء تشكليها

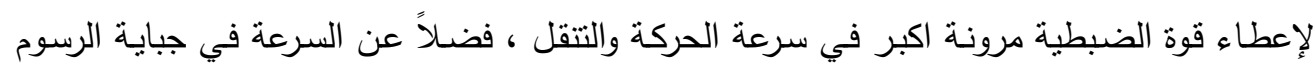

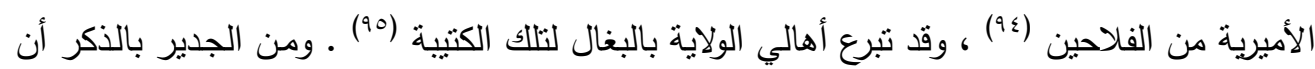

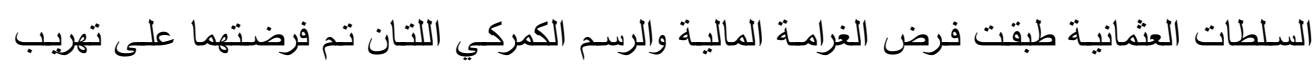

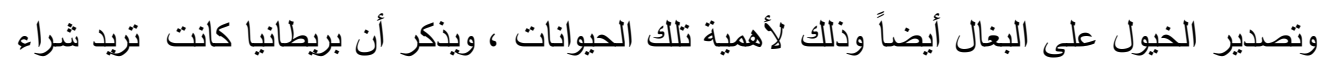

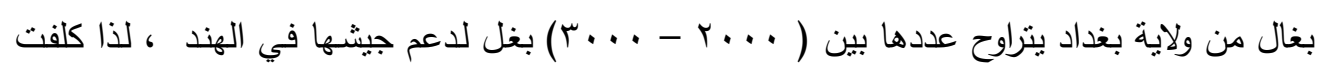

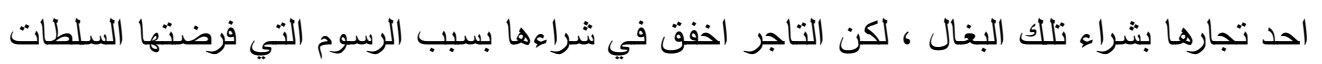

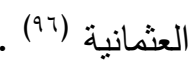

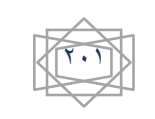




\section{r- r أهميتها في النقل وخدمات البريد :}

أمسا بالنسبة لمجال النقل ، فقد كانت الخيول والجمال والبغال والحمير من وسائل النقل

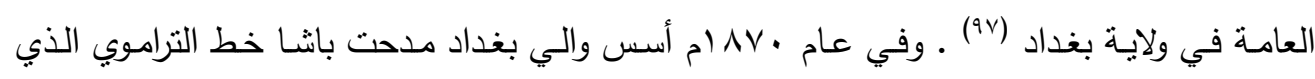

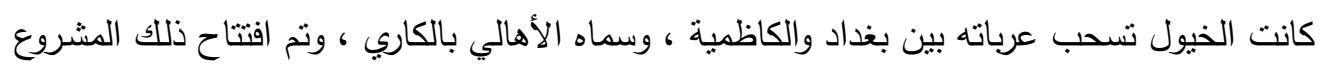

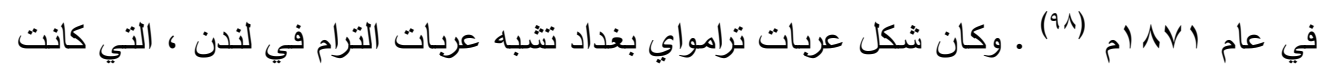

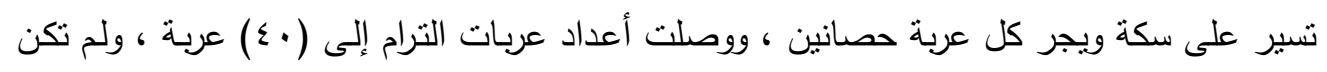

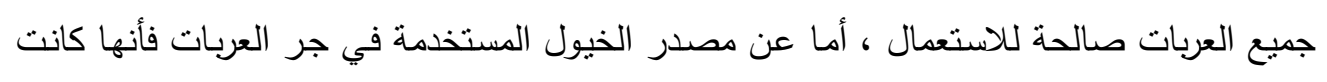

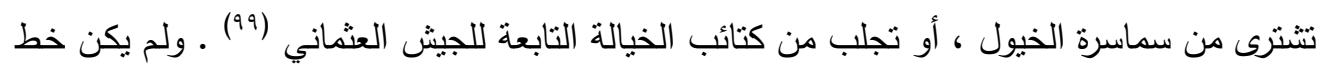

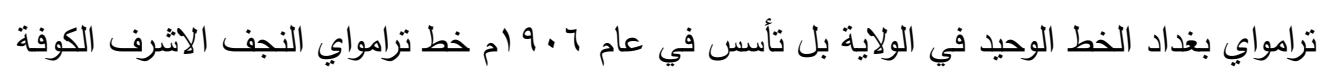

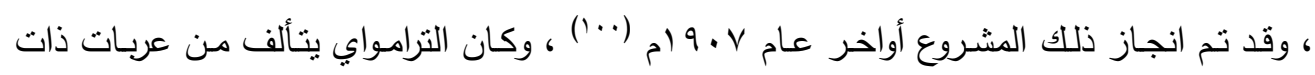
طابقين تجرها الخيول على سكة حديدية (1.1) ـ وكانت العربات التي تجرها الخيل إحدى أهم وسائط

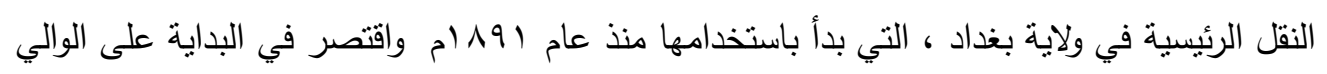

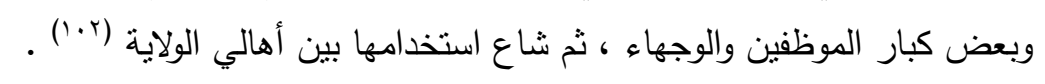

وفي أوائل القرن العشرين الميلادي قام عدد من تجار بغداد بتأسبس شـركة تتولى نقل

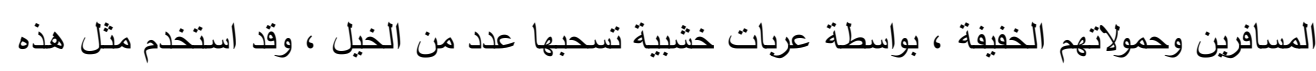

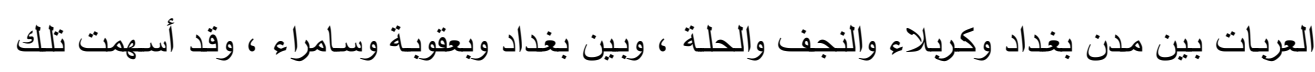

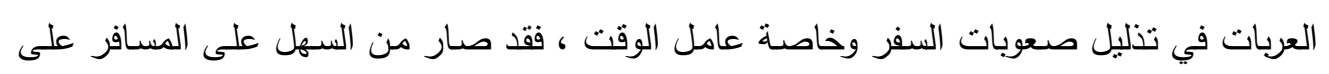

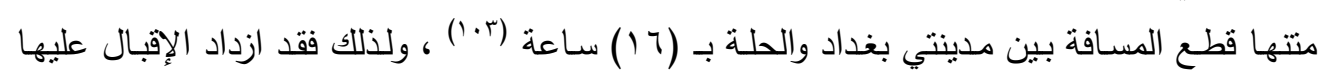

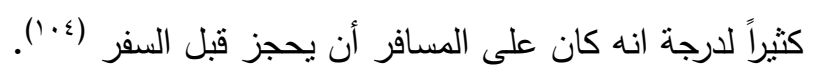

ووفقاً لإحصائية صدرت في عام 9 ام فأن مجموع العربات التي كانت نسير بين بغداد

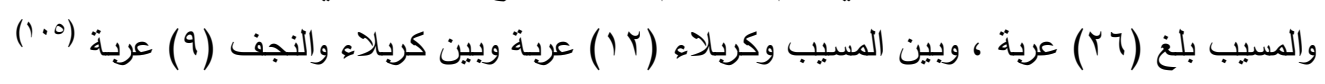

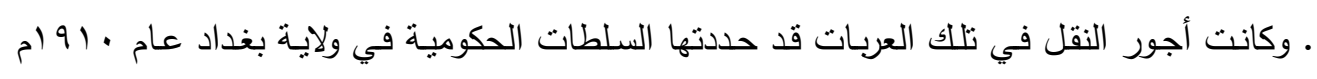

\section{陑}


العـــــــد الثاني والعشرون

\section{مجلـــة كلبــــة التربيــــة}

بعشرين قرشاً للشخص الواحد ، وإضافة مبلغ عشر بارات عن كل (1 (1) كغم من المواد أو البضائع التي يستصحبها المسافر معه (†.1) .

كما استخدمت حيوانـات الحمير والبغـال والجمال في حمل ونقل البضـائع من والى ولايـة

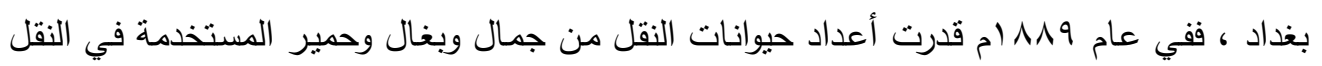

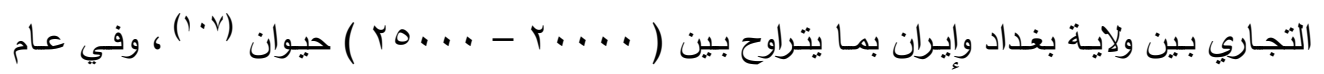

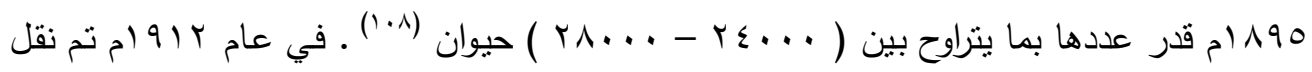

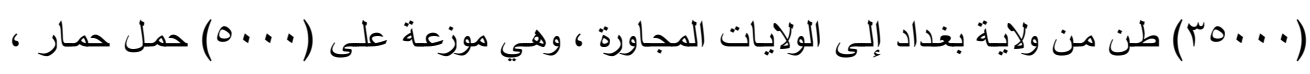

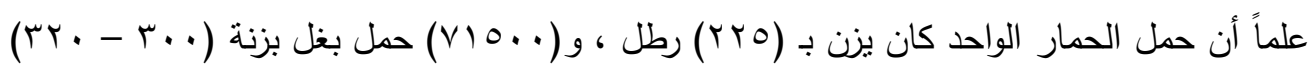

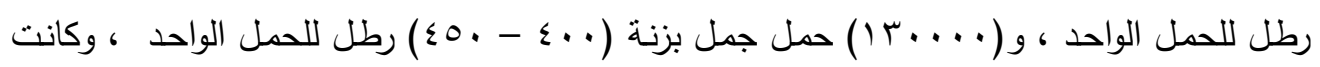

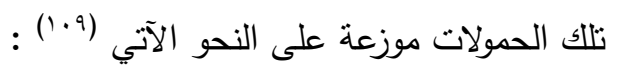

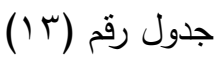

حمولات حيوانات النقل في ولاية بغداد عام r جام روب

\begin{tabular}{|c|c|c|}
\hline الوزن / حمل & حيوان النقل & الطريق \\
\hline ז.... & الجمل & \multirow[t]{2}{*}{ بغداد - كرمنشاه - همذان } \\
\hline$\varepsilon \ldots$ & 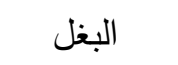 & \\
\hline$\leqslant 0 \ldots$ & 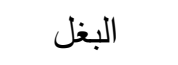 & بغداد - حلب - دمشق \\
\hline$v \cdots$ & 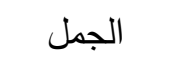 & \multirow[t]{3}{*}{ بغداد - الموصل } \\
\hline r... & 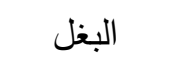 & \\
\hline $0 \ldots$ & الحمار & \\
\hline $1 V \ldots$ & 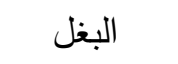 & بغداد - السليمانية \\
\hline r... & 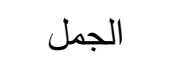 & بغداد - كربلاء - النجف \\
\hline $10 \ldots$ & 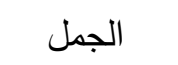 & بغداد - الحلة \\
\hline $1 \ldots$ & 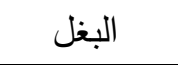 & بغداد - مندلي - بدرة \\
\hline $10 \ldots$ & 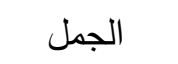 & بغداد - الناصرية \\
\hline
\end{tabular}




\section{العـــــــد الثاني والعشرون}

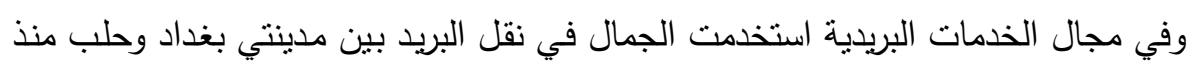

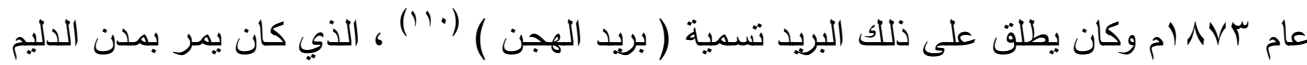

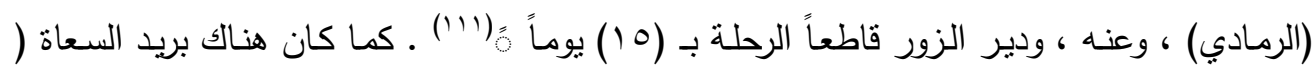

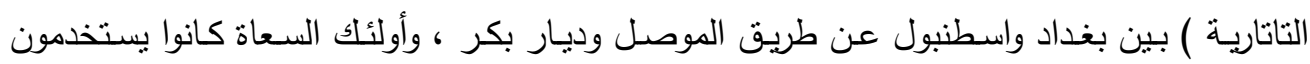

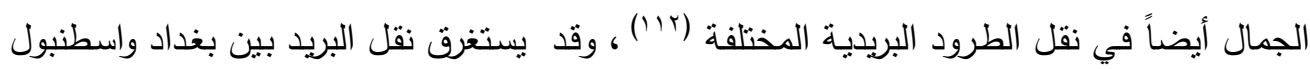

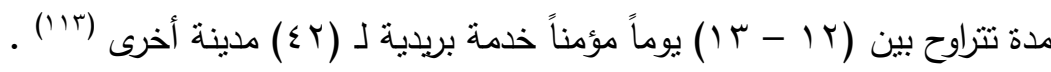

\section{سادساً : الإجراءات الحكومية العثمانية لحماية الثروة الحيوانية والاهتمام بها .}

أولت الدولة العثمانية الثروة الحيوانية اهتماماً كبيراً ، وقد تمثل ذلك بفتح مكتب أو المدرسة

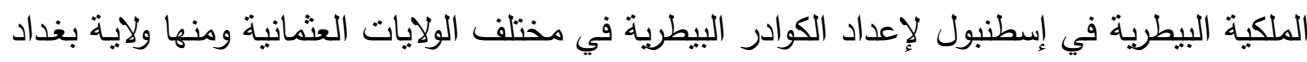

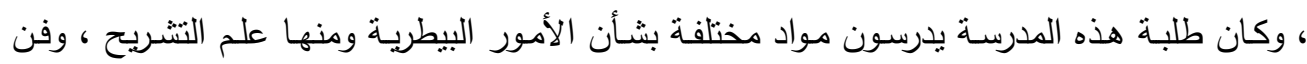

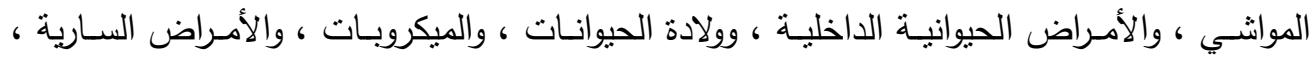

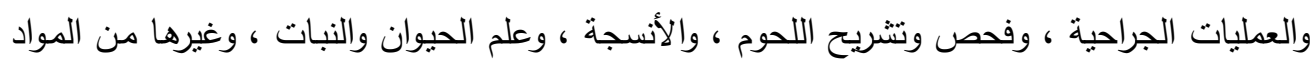

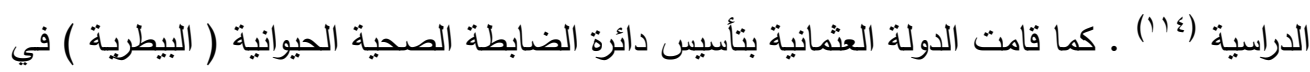

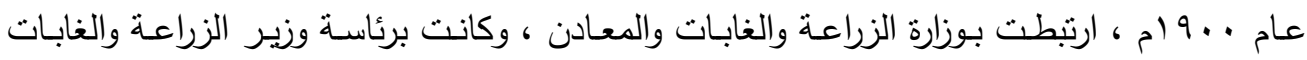

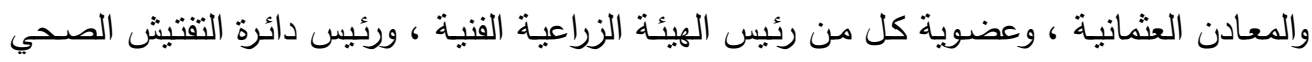

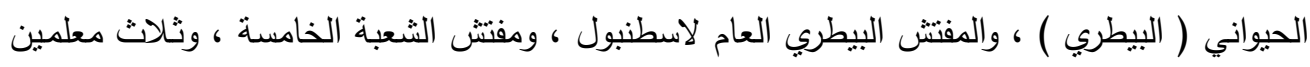

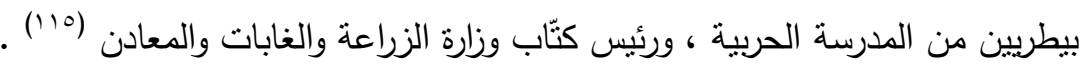

وقد نم فتح عدة فروع لهذه الدائرة في مراكز الولايات العثمانبة الأخرى ، وكانت ولاية بيروت

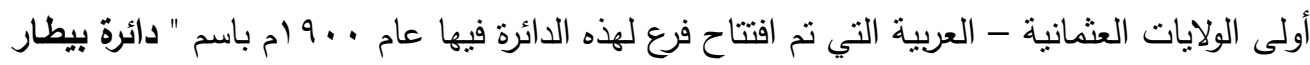

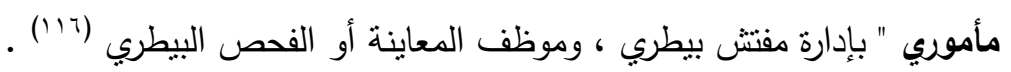
أمـا في ولايـات العراق العثمانيـة فقد تأخر تشكيل هذه الدائرة في ولايـة بغداد حتى عـام

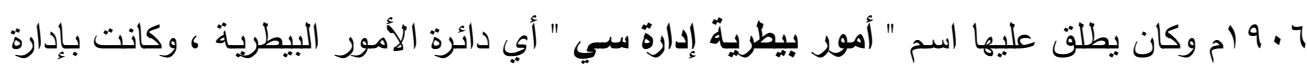

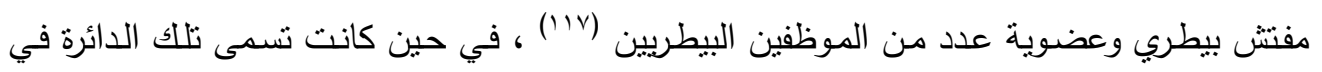


ولايـة الموصل باسم " مـأمورين بيطريـة " وكانت بإدارة المفنش البيطري ، وعضوية موظف بيطري واحد (1) (1)

وكانـت مهمـة هذه الدوائر البيطريسة هـي إرسـال موظفيها البيطريبين إلى المنـاطق الريفيـة

المختلفة ، والمناطق التي ترعى فيها الماشية لعلاجها من الإمراض التي قد تصيبها ، فعلى سبيل المثال في عام ب او ام تم إرسال فاروقي أفندي المفتش العام البيطري لولاية بغداد إلى قضاء خراسان ، للوقوف على أسباب إصابة الأغنام في ذلك القضاء بالمرض (19") ـ ومن الجدير بالذكر أن ابرز

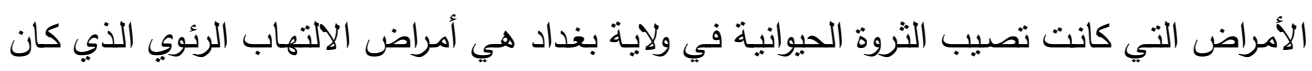

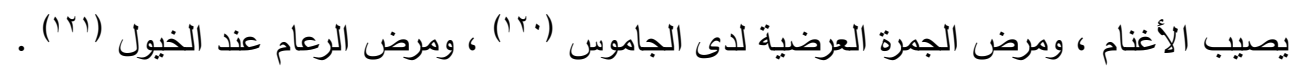

وفي 9 ا نيسان سا 9 ام أصدرت الدولة العثمانية قانون للحد من سرقة الحيوانات تألف من

(Y. ) مادة قانونية ، وفي ذلك القانون أجبرت المادة ( ( ) على كل شخص أراد أن بييع حيواناً فعليه

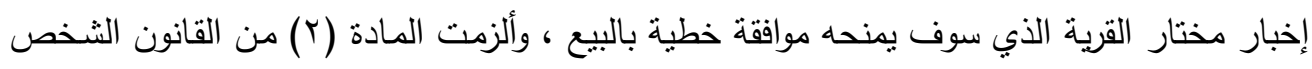

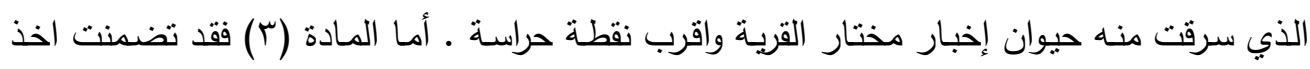
أوصاف الحيوان المسروق وأعمامها على مختاري القرى المجاورة ونقاط الحراسة ومدير الناحية ـ كما

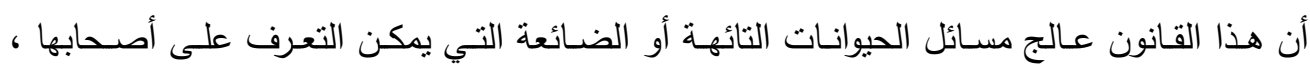
والضالة التي ليس لها مالك (rri) . 
ا- كانت الولايات العثمانية الثلاث في العراق من بين الولايات العثمانية الأكثر عدداً في مقدار الحيوانات ، وكانت ولاية بغداد في عام الو ام تأتي بالمرتبة الثالثة في أعداد الأغنام فيها

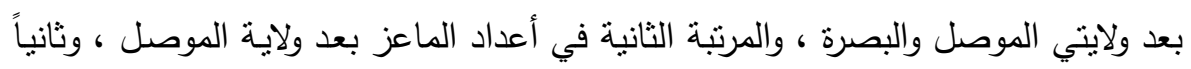

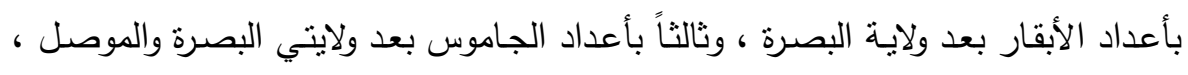
وجاءت بالمرتبة الثانية بعدد الحيوانات الداجنة بعد ولاية البصرة ، في حين شغلت المركز الأول بمـا تملكهه مـن جمال ، وجاءت بـالمركز الثالث بأعداد الخيول والحمير ، والمركز

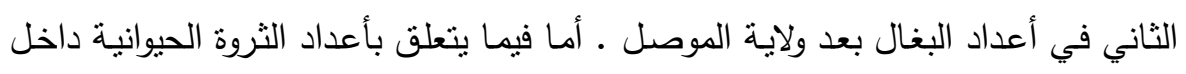

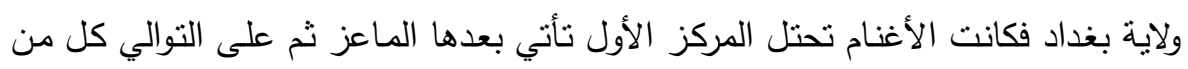
الجمال والأبقار والجاموس ولأندان

ץ- كانت تربية حيوانات الأغنام والماعز والأبقار في ولاية بغداد خلال العهد العثماني الأخير تمثنّ دعامة للاقتصاد العام للولاية والاقتصاد الخاص بالأهالي ( الاقتصاد المنزلي ) إذ لم يخلُ أي بيت في كل مدن وبلدات وقرى الولايـة إلا ووجد فيه احد أنواع تلك الحيوانات

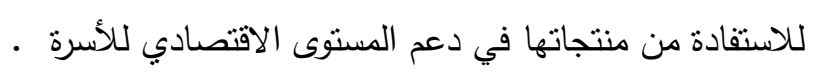

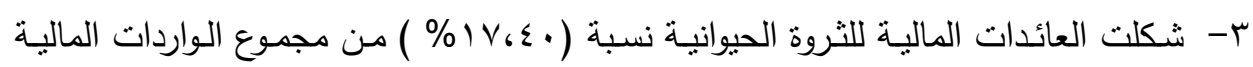

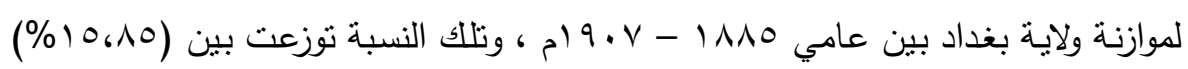

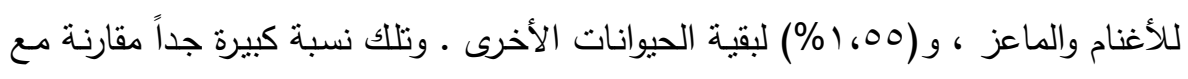
أبواب الإيرادات المالية الأخرى في الموازنة مما يدل على أهمية الثروة الحيوانية في دعم النشاط الاقتصادي للولاية ـ كما شكلت الواردات المالية للثروة الحيوانية في ولاية بغداد نسبة

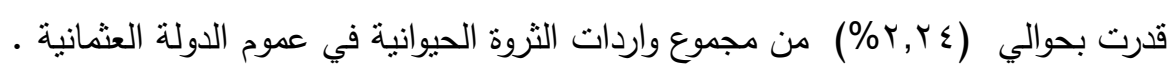
ع - يمكن تفسير تذبذب كمية الواردات المتحققة من رسوم وضرائب الثروة الحيوانية بتأثز تلك الثروة بمختلف الظروف والعوامل الطبيعيـة والجغرافيـة التي انعكست أيضـاً على أعدادها

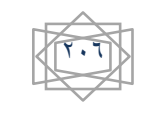




\section{العـــــــد الثاني والعشرون}

\section{مجلـــة كليــة التريبــة}

التي انخفضت أواخر العهد العثماني مقارنـة في تسعينيات القرن التاسـع عشر للميلاد .

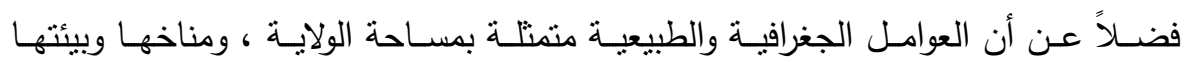

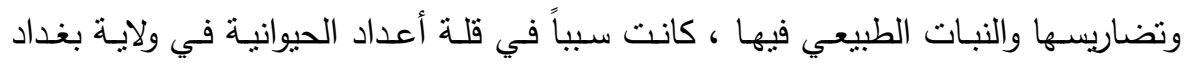
مقارنة مع ولايتي الموصل والبصرة . ملنات

0- كانت الضرائب والرسوم التي فرضتها الدولة العثمانية على الثروة الحيوانية كرسوم الكودة

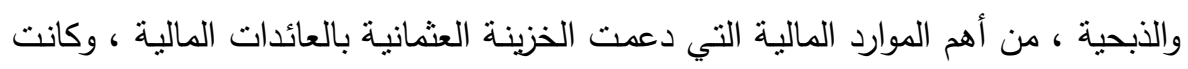

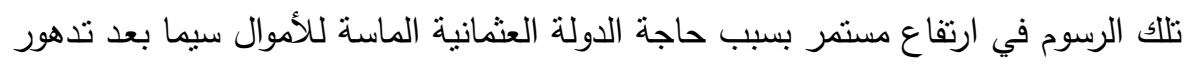

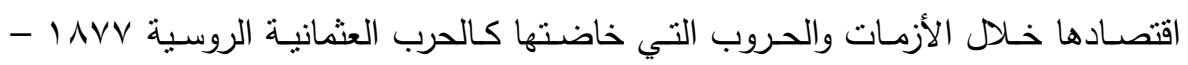

$$
\text { 1AVA }
$$

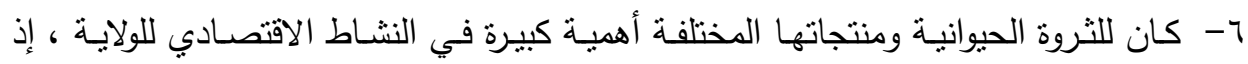

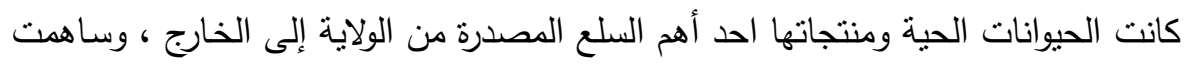

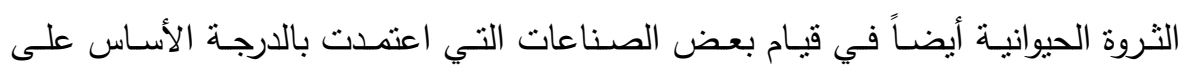

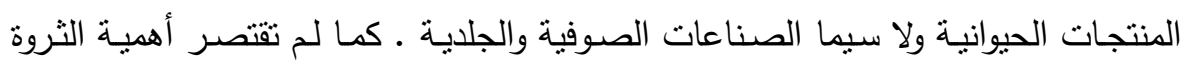
الحيوانية على مجالات التجارة والصناعة بل تعداها إلى الجانب العسكري حينما استخدم

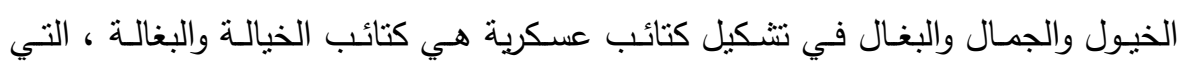

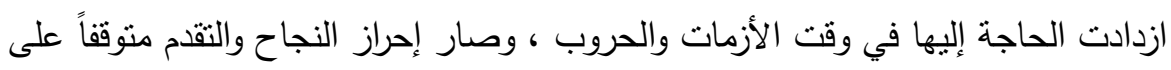

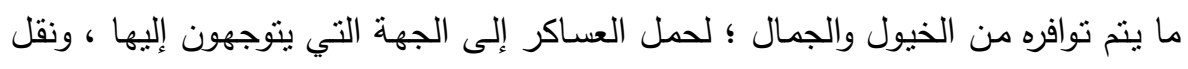

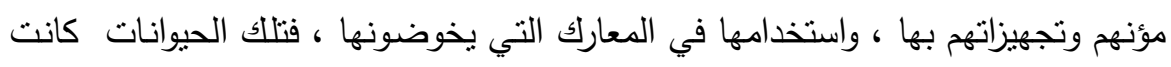

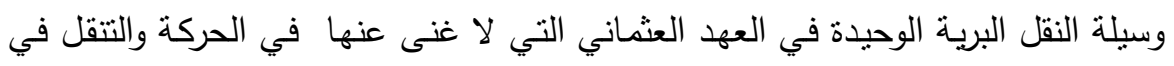
المنطقة، ونتوقف عليها حركة القطعات العسكرية.

V - كان وقوع ولاية بغداد في عقدة مواصلات التجارة البرية بين الثرق والغرب ، قد خلق حاجة

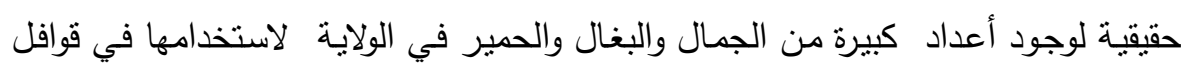

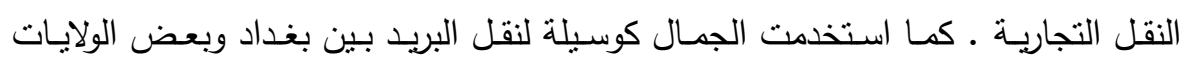


العـــــــد الثاني والعشرون
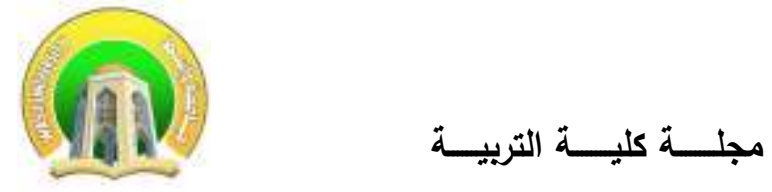

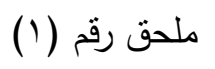

دفتز تعداد الأغنام في لواء بغداد عام 0 ـ 9 (م (Tr)

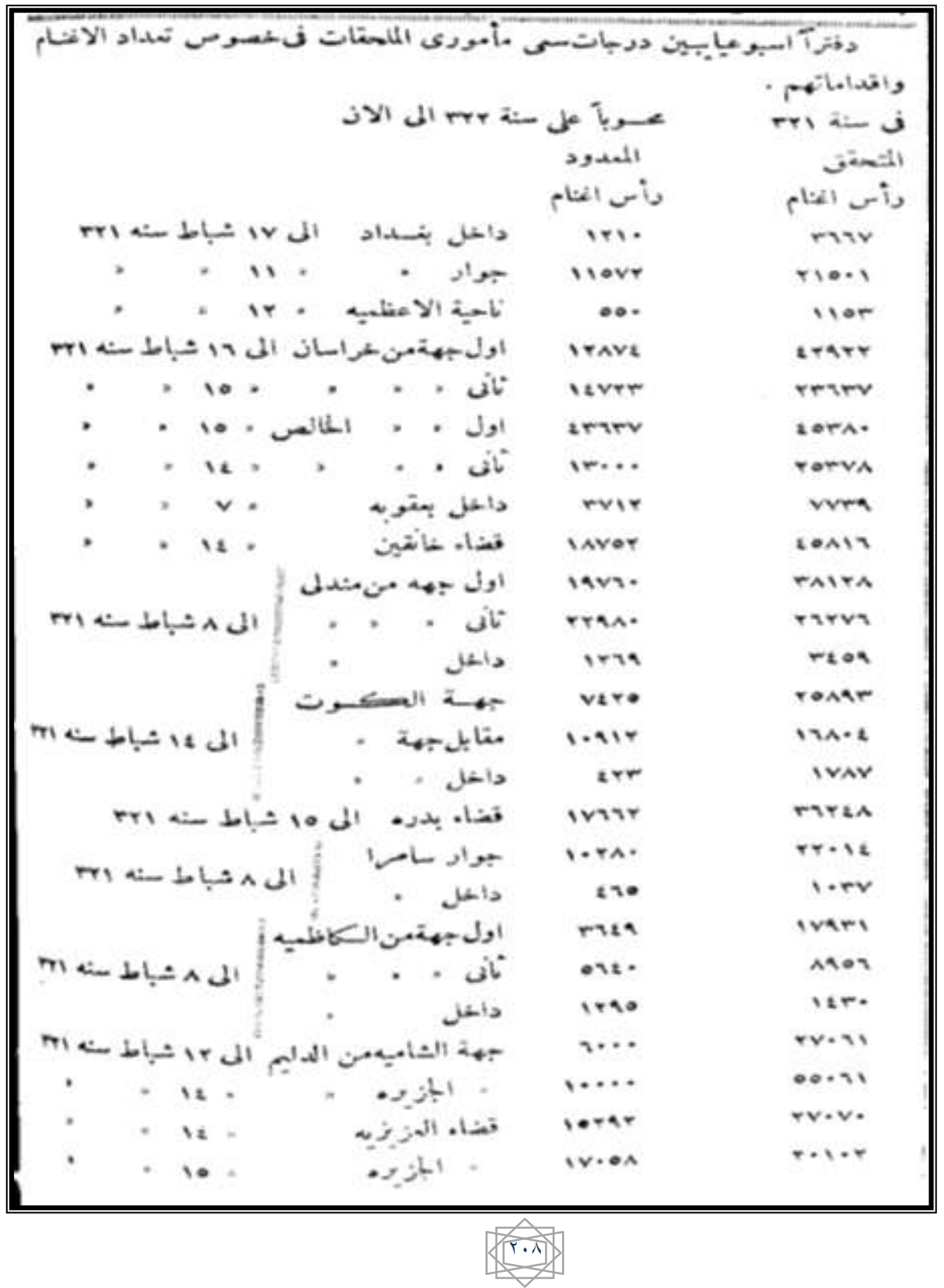


العـــــــد الثاني والعشرون

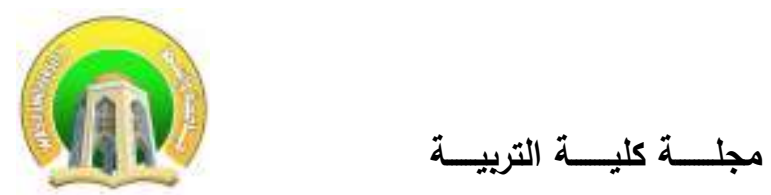

ملحق رقم (r)

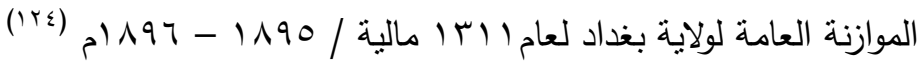

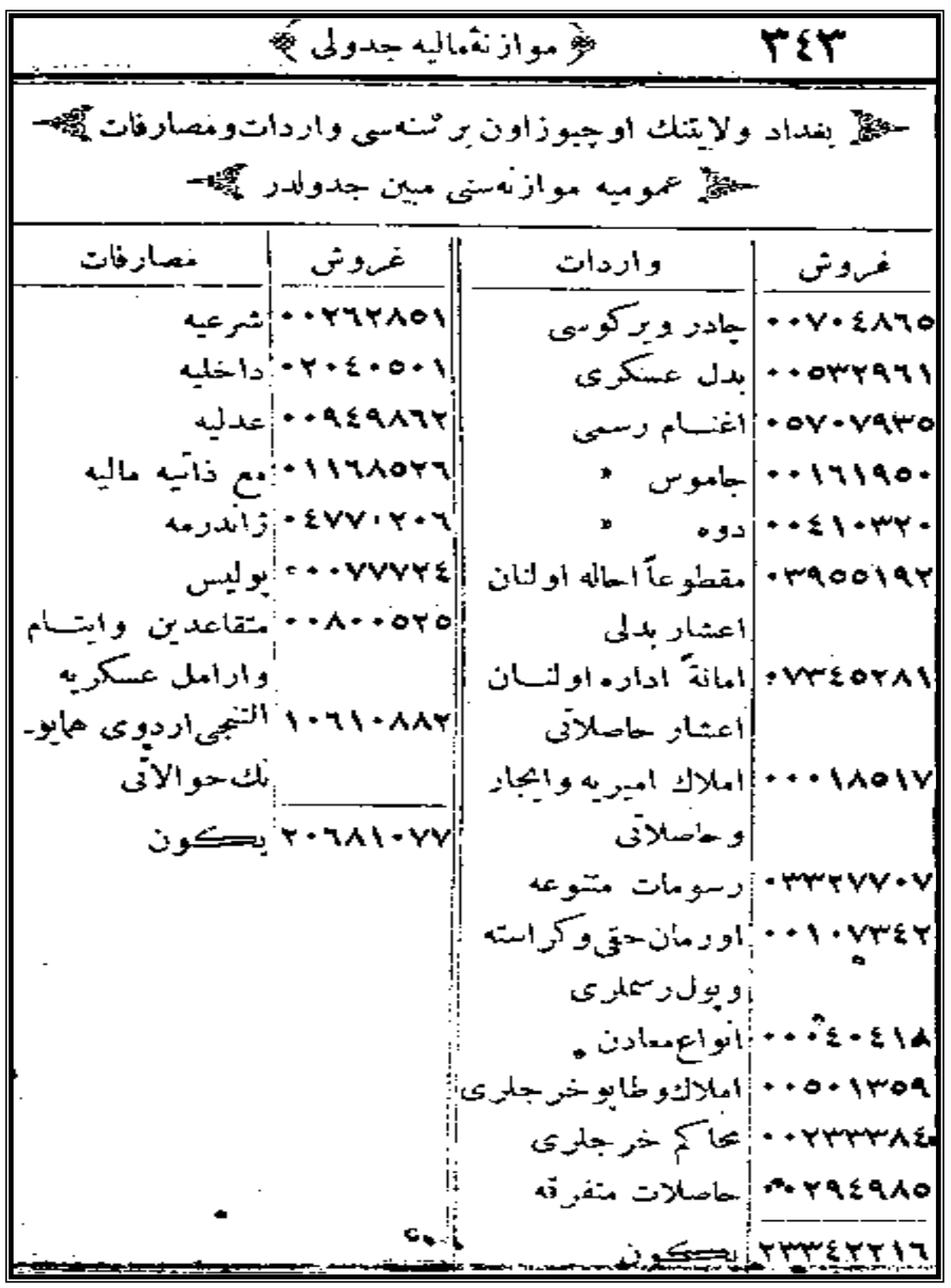


العــــــدد الثاني والعشرون

ملحق رقم (r) - مل

الموازنة العامة لولاية بغداد لعام ابس امالية / 19.0- 19 (190 (ro)

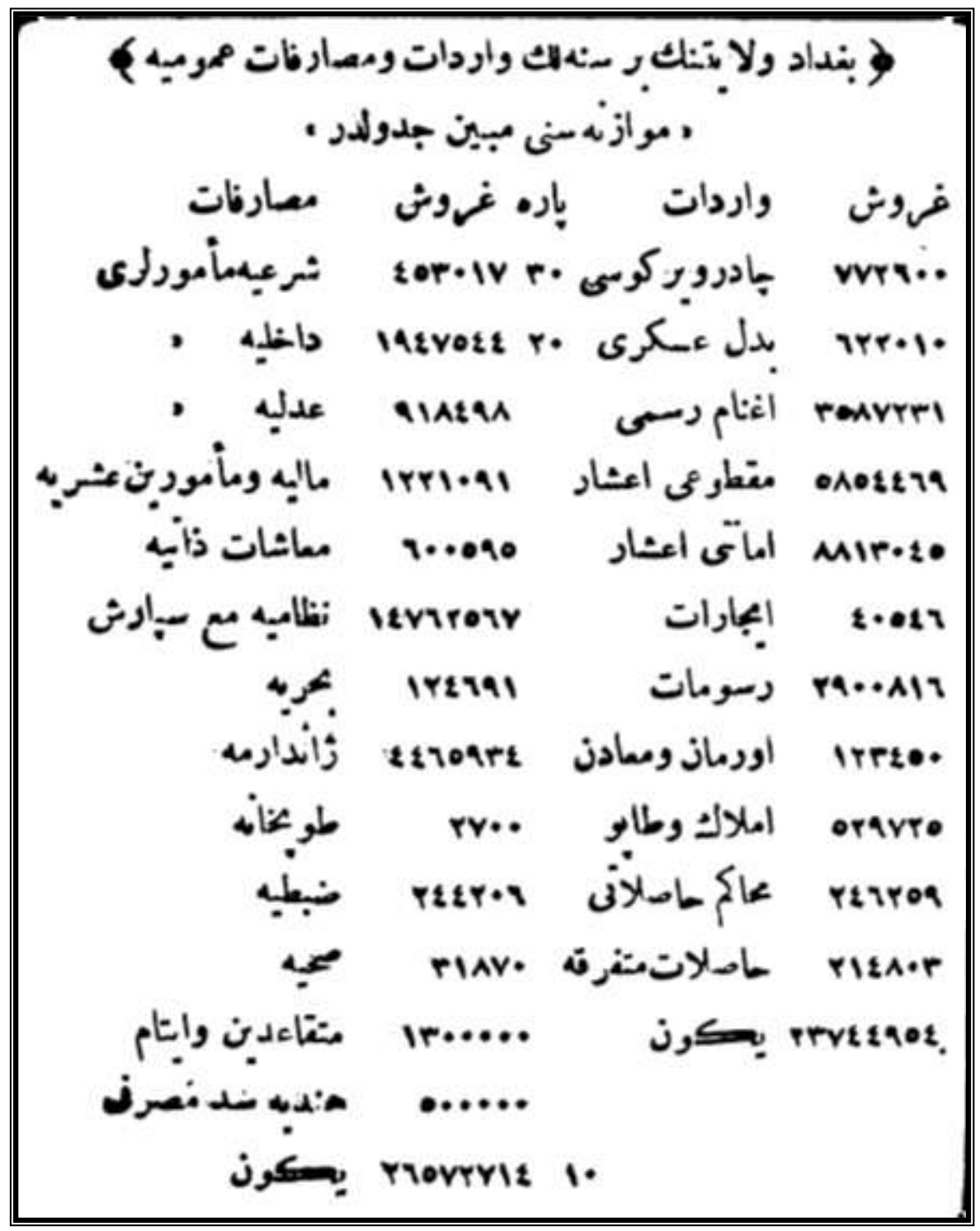


(1) Vital Cuinet, Turguie d Asia, tome troisieme , ( Paris : 1894 ), p 22.

(r) ملحوظة : جميع الجداول الواردة في البحث هي من عمل الباحث باستثاء جدول رقم (ع) . ( ) (

(3) Ibid , p p 106, 153, 192 .

() ) تجارت وزراعت نظارتي ، استاتستيق اداره عموميه سي مديرتي ، ممالك عثمانية نك وب إ سنه مخصوص زراعت

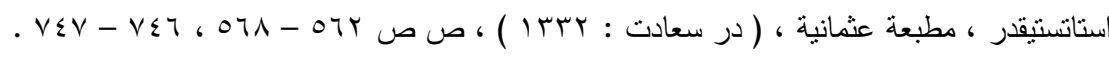

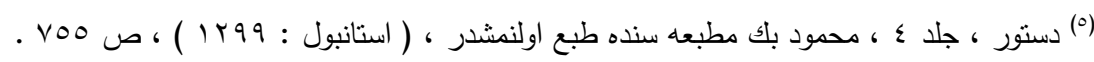

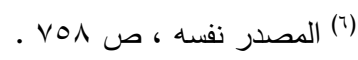

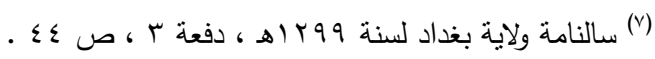

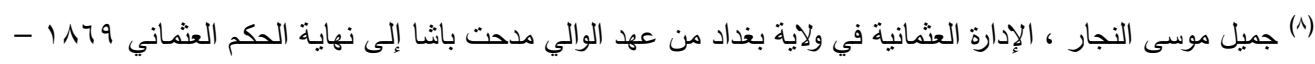

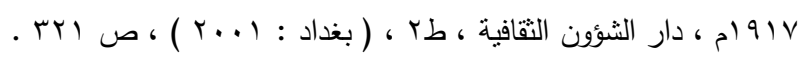

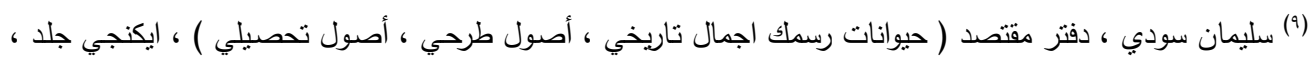

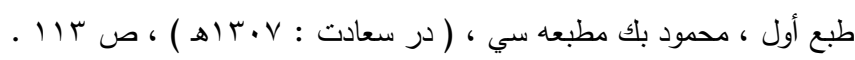

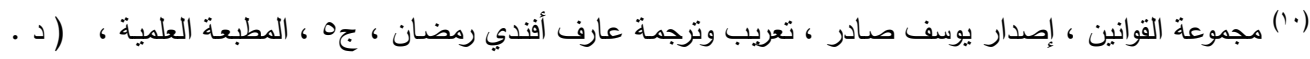

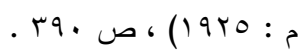

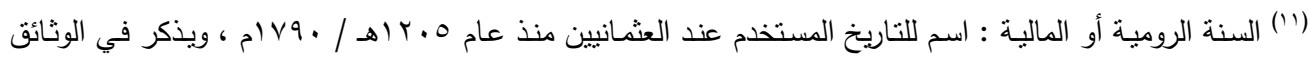

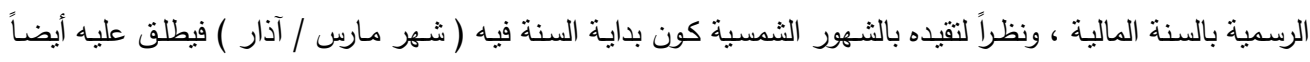

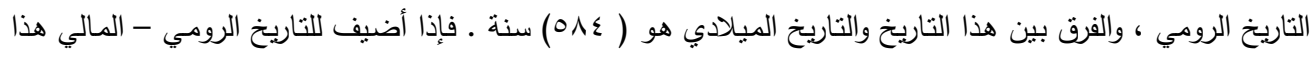

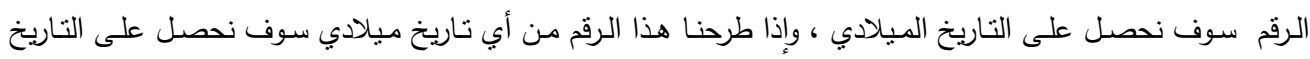

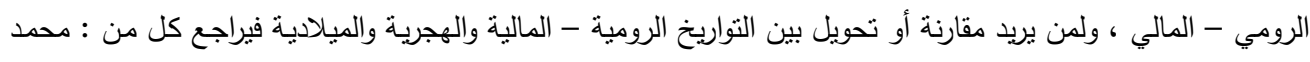

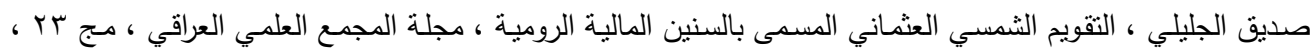

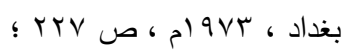

Faik Resit Unat, Hicri Tarihleri Miladi Tarihe Cevirme Kilavuzu , (Ankara : 1988 ) .

(r') للاطلاع على الولايات العثمانية الأخرى في عام 9 الم ام ، ومعرفة التقسيمات الإدارية في عموم الولايات العثمانية .

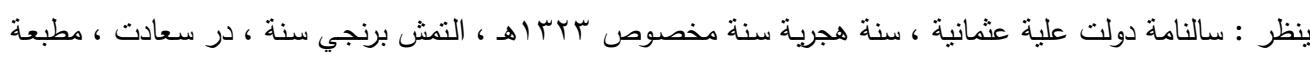

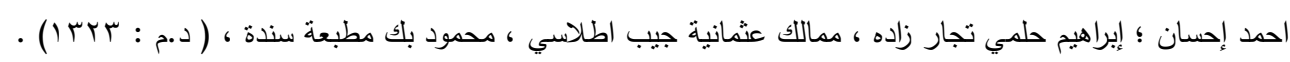

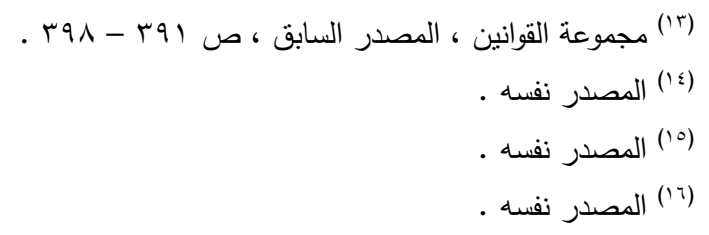




\section{العـــــــد الثاني والعشرون}

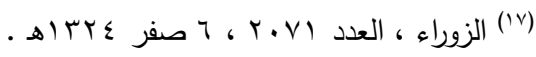

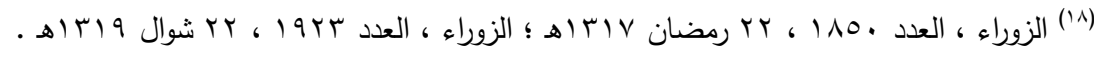

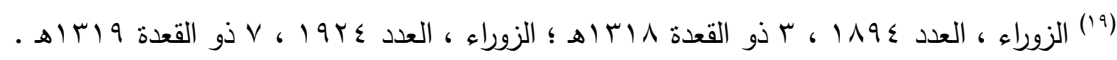

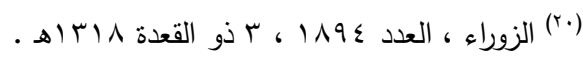

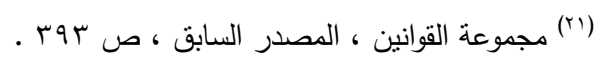

(rr) القرش : عملـة نقديـة فضية أخذها العثمانيون عن الأوربيين ، وقد ضـربت لأول مـرة في الدولـة العثمانيـة في عهد

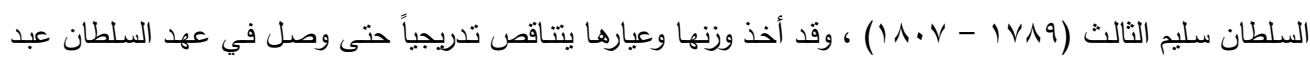
الحميد الثاني إلى أقل من نصف درهم ـ أما بالنسبة إلى معادلتها بالبارة ، أو الاقجة فأن القرش كان بساوي ( • ع) بارة ،

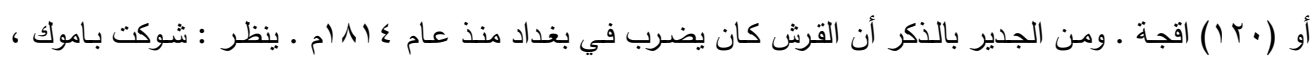

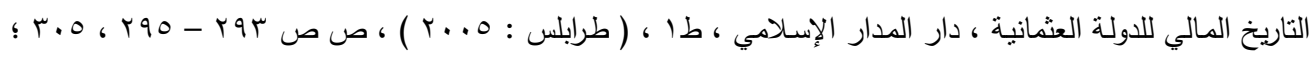
عباس العزاوي ، تاريخ النقود العراقية لما بعد العهود العباسية ، شركة التجارة والطباعة ، ( بغداد : 1901 ) ) ص ص $.1 \leqslant \Lambda-$

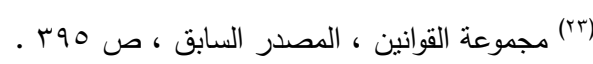

(24) Stanford J. Shaw , Ezel Kural Shaw, History of the Ottoman Empire and Modern Turkey, vol II , Cambridge University press , ( Edinburgh : 2002 ), p 99 .

(ro) غانم محمد علي ، النظام المالي العثماني في العراق

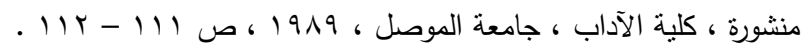

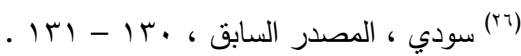

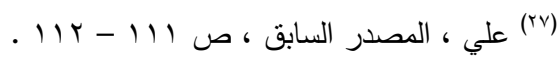

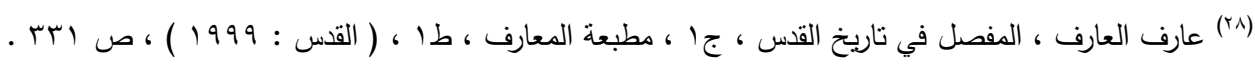
(99) أثـار احد البـاحثين إلى أن مقدار الضـريبة المفروضـة على الجمـال و الجـاموس في ولايـات العراق أواخر العهد العثماني كان (0؟) سنت أمريكي ، وهو ما يعادل (• (1) قروش عثمانية نقربياً بالاعتماد على أسعار العمـلات الأجنبية

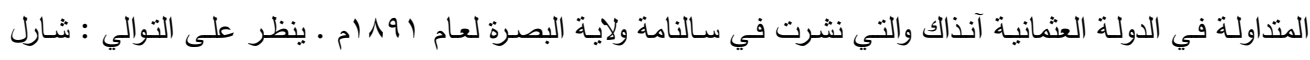

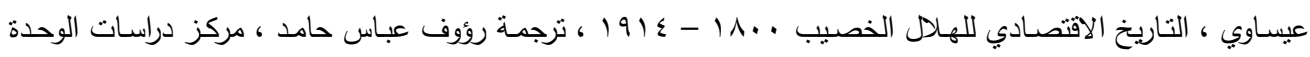

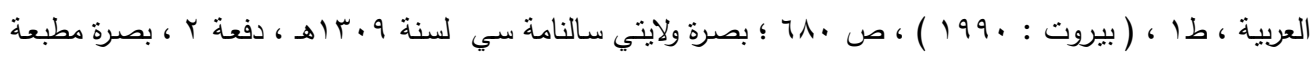

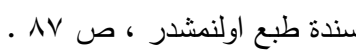

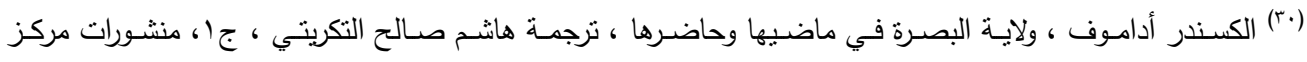

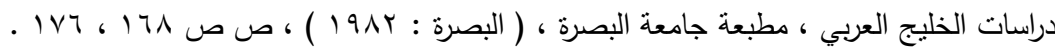

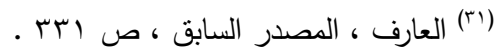

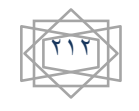




\section{العـــــــد الثاني والعشرون}

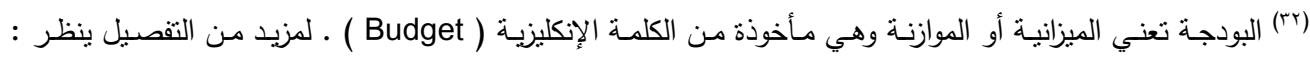

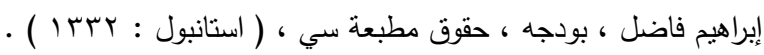

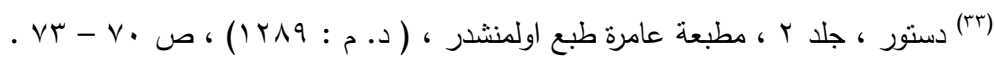
(r) ا

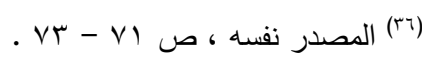

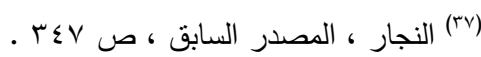

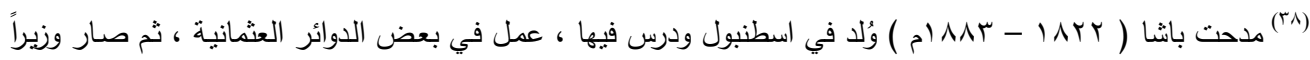

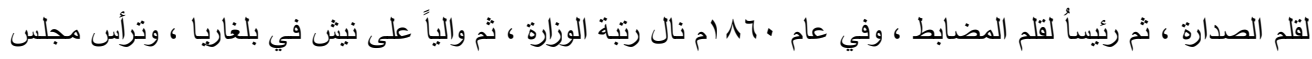

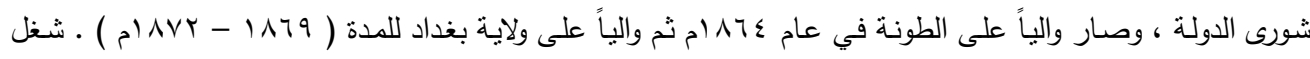

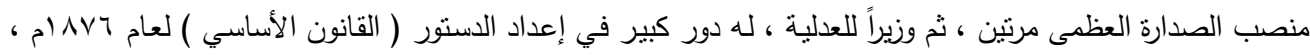

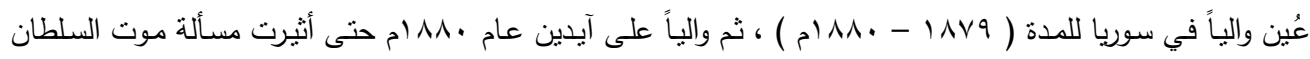

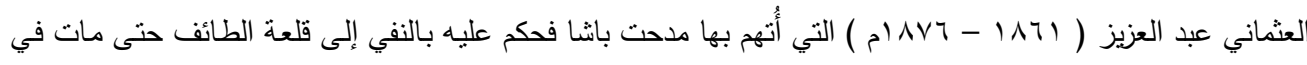

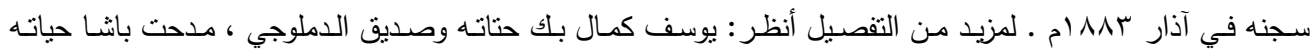

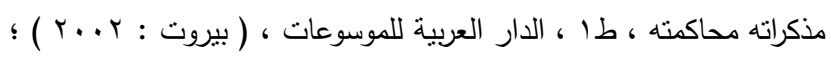

Ali Haydar Midhat Bey, The Life of Midhat Pasha , (London : 1903 ), p 15 - 37 .

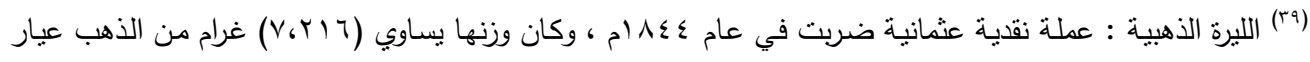

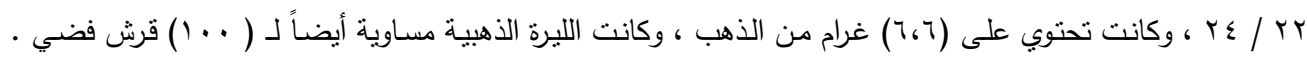

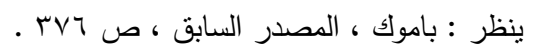

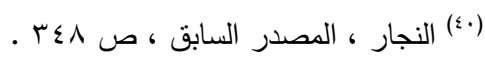

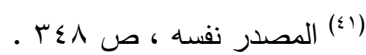

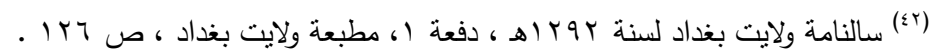

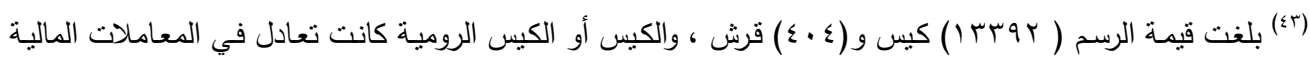

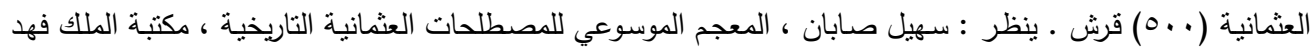

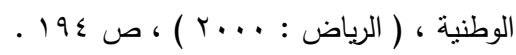

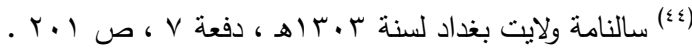

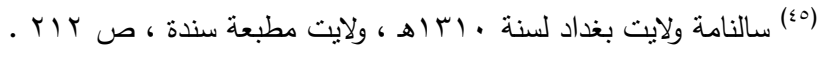

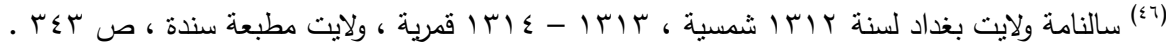

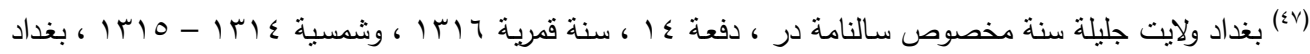

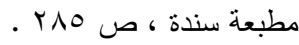

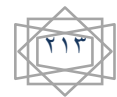




\section{العـــــــد الثاني والعشرون}

\section{مجلـــة كليــــة التربيـــة}

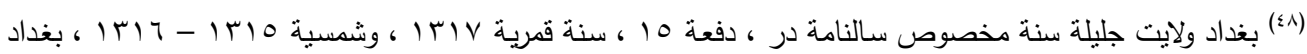

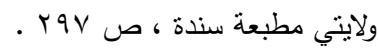

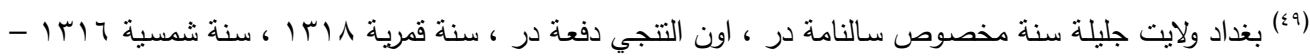

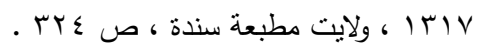

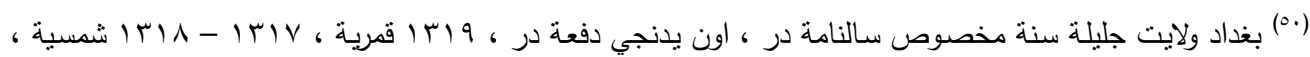

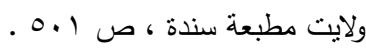

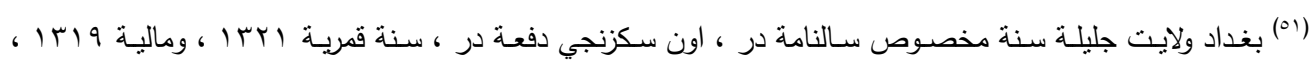

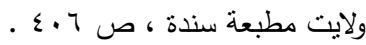

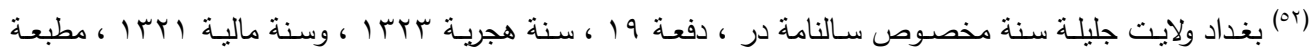

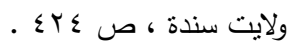

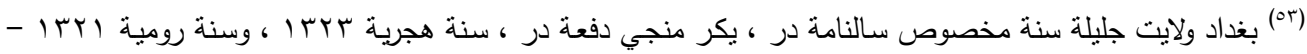

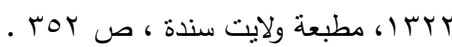

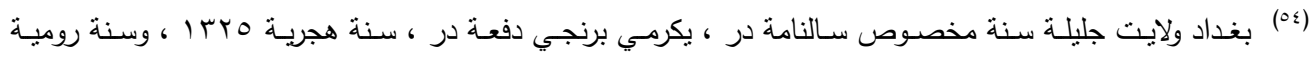

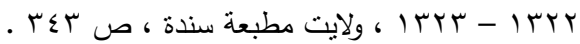

${ }^{(55)}$ Tevfik Guran , Osmanli Mali Istatistikleri Butceler 1841 - 1918 Ottoman Financial Statistics Budgets , ( Ankara : 2003 ) p $74-146$.

${ }^{(56)}$ Keiko Kiyotaki , Ottoman State Finance : A study of Fiscal Deficits and Internal Debt In 1859 - 63, working paper No. 90/05 , London School of Economics , April , 2005 , p 31 .

${ }^{(59)}$ Kiyotaki, Op.cit , p 31 .

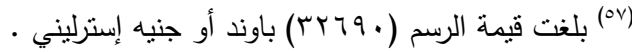

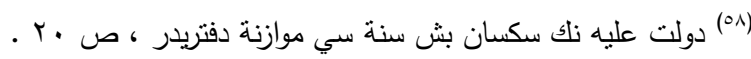

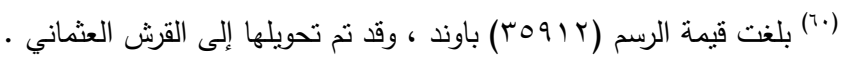

${ }^{(61)}$ Stanford J. Shaw , The Nineteenth - Century Ottoman Tax Reforms and Revenue System , International Journal of Middle East Studies, Vol. 6 , No. 4 (Oct., 1975), p 453.

(62) Ibid, p 453 .

$$
\text { (r) }
$$

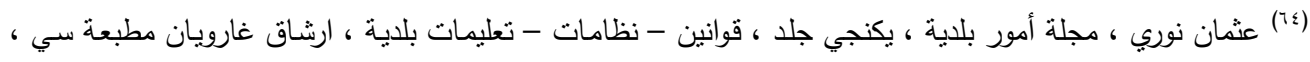

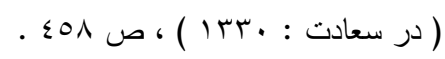

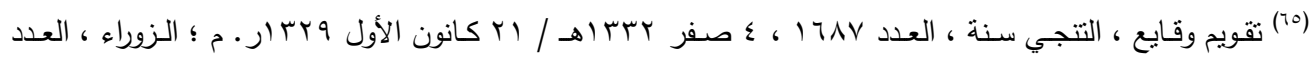




\section{العـــــــد الثاني والعشرون}

\section{مجلـــة كليـــة التربيـــة}

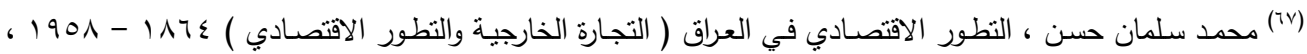

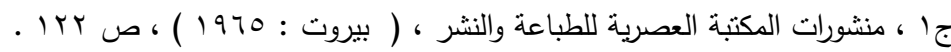

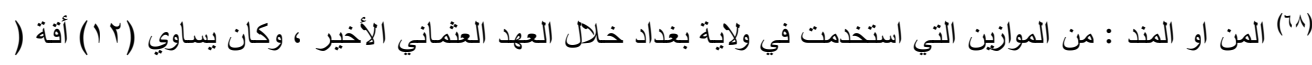

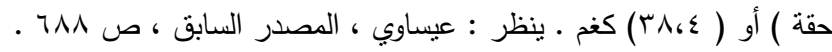

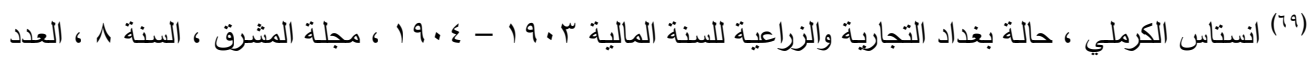

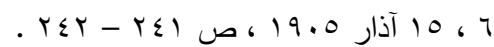

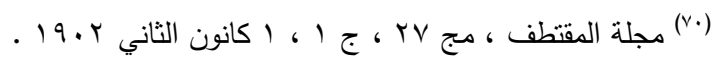

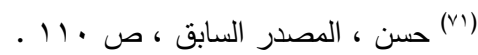

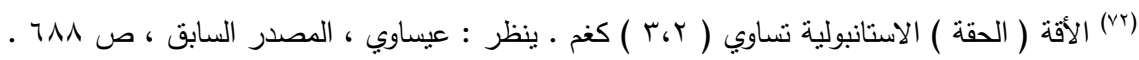

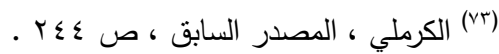

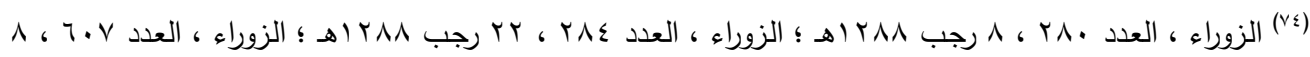

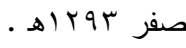

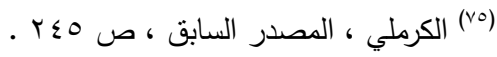

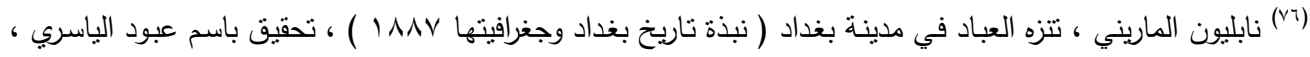

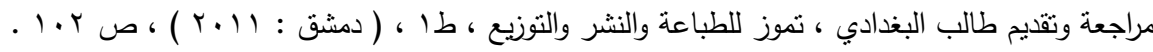

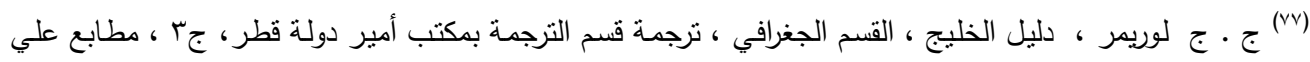

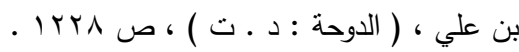

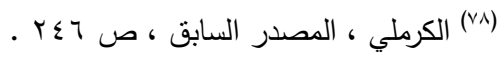

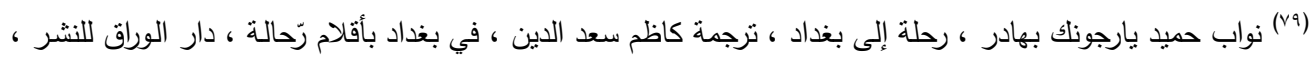

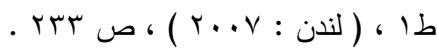

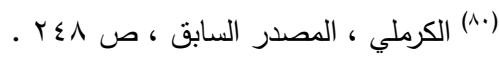

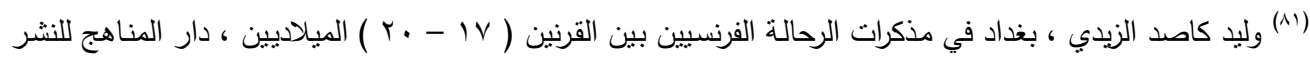

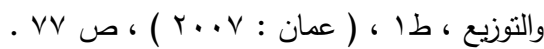
${ }^{(82)}$ Charles Issawi, The Economic History pf the Middle East 1800 - 1914 , the university of Chicago press , ( Chicago : 1966 ), p 184.

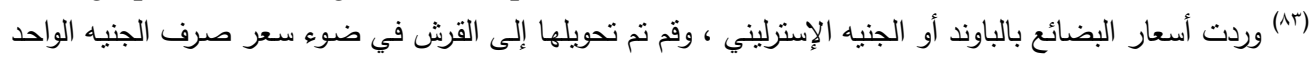

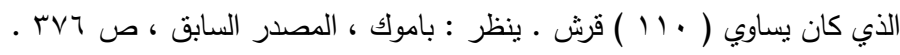

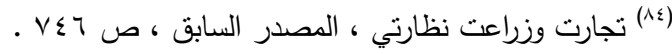

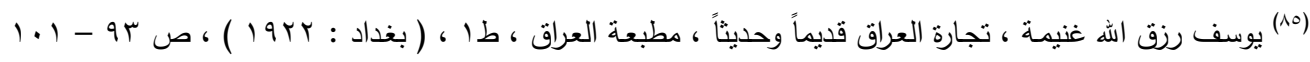




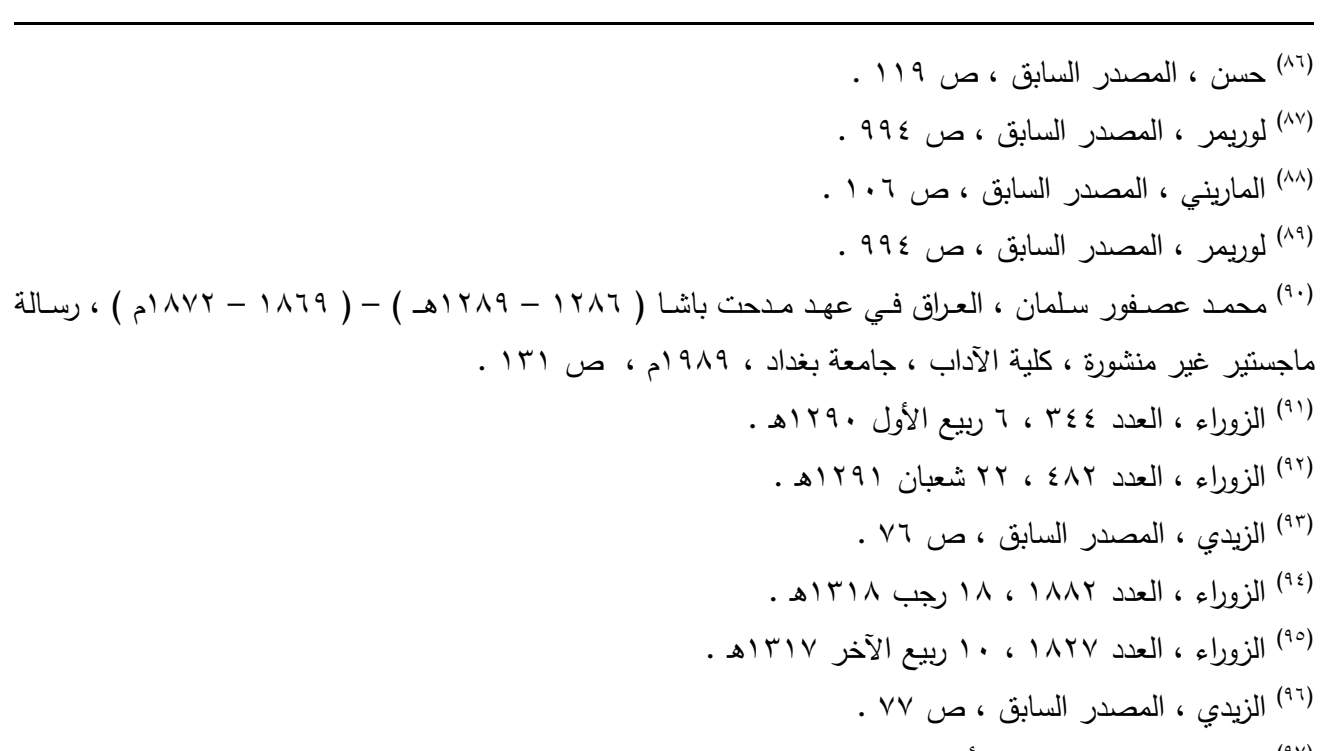

(9V ستيفن هيمسلي لونكريك ، أربعة قرون من ناريخ العراق الحديث ، نقله إلى العربية جعفر الخياط ، ط؛ ، ( بغداد :

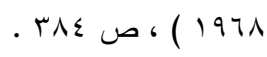

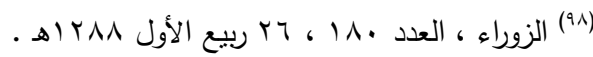

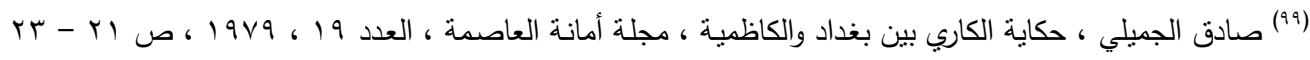
(..") جعفر الثيخ باقر آل محبوبة ، ماضي النجف وحاضرهـا ، ج) ، طץ ، مطبعة الأضواء ، ( بيروت : 9 . . ) ) ، .

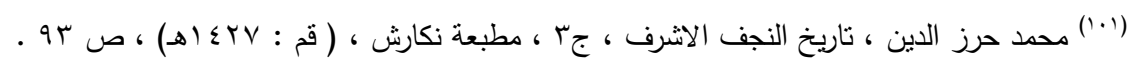

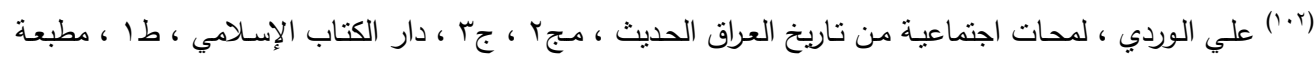

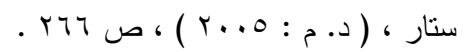

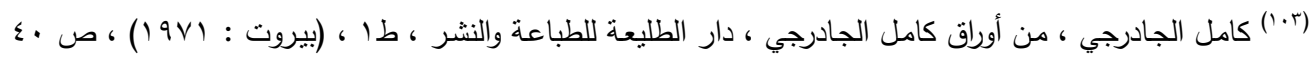

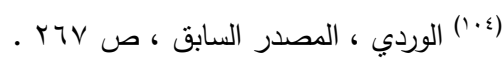

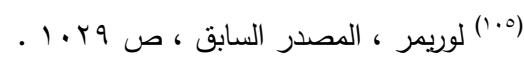

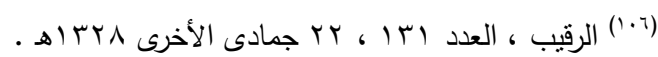

${ }^{(107)}$ George N . Curzon, Persia and the Persian Question, Vol II , ( London : 1892 ), p 577.

${ }^{(108)}$ Walter B . Harries, From Batum to Baghdad via Tiflis, Tabriz, and Persian Kurdistan , ( Edinburgh : n.d. ), p 298

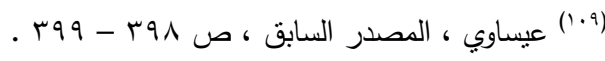


(•"') عباس العزاوي ، ناريخ العراق بين احتلالين ، جی ، شركة التجارة والطباعة المحدودة ، ( بغداد : 1907 ) ، ص

${ }^{(112)}$ Cuinet, Op . cit, p 181 .

(ז'(1) سعاد هادي العمري ، بغداد كما وصفها السواح الأجانب في القرون الخمسة الأخيرة ، مطبعة المعرفة ، ( بغداد :

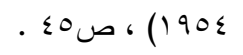

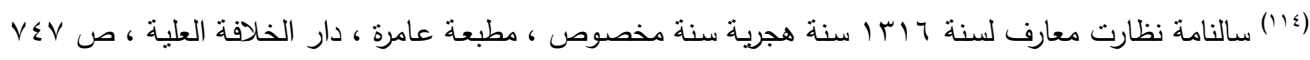

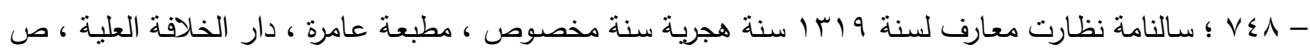
r ror-rol

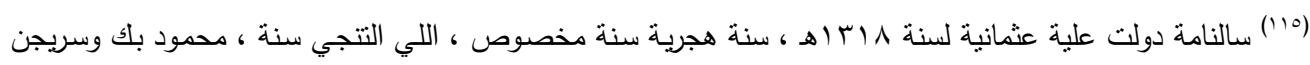

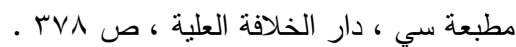

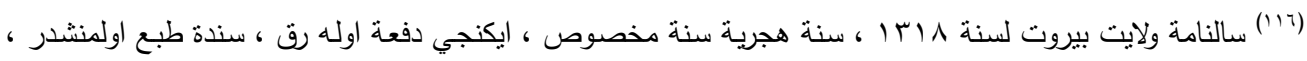

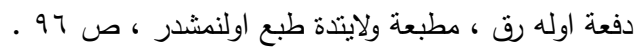

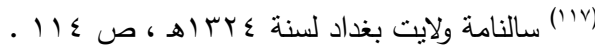

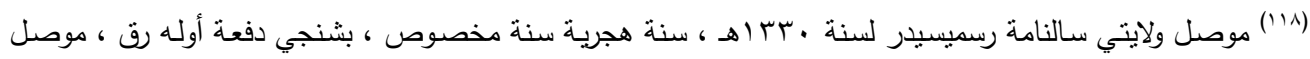

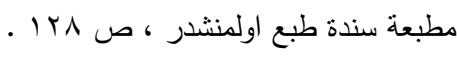

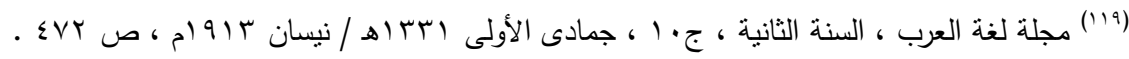

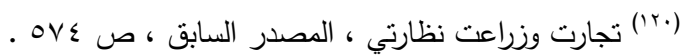

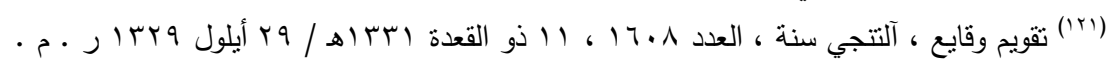

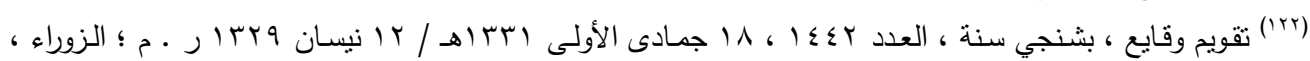

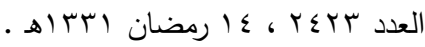
(ال) الزrr)

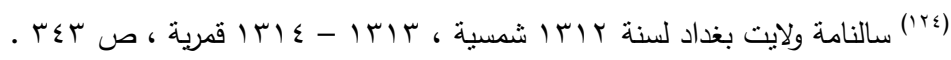

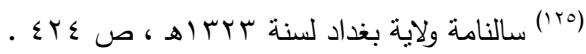


أولاًا : الوثائق العثمانية المنشورة .

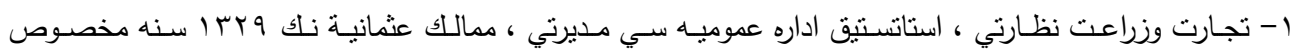

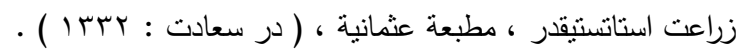

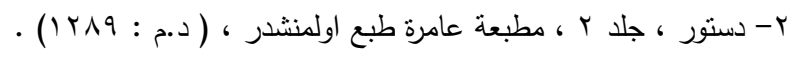

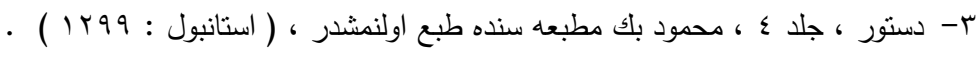

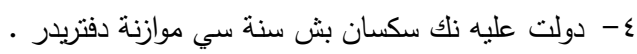

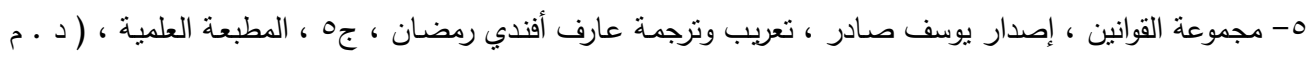

. (19ro:

ثانياً: الحوليات ( السالنامات ) العثمانية .

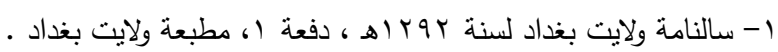

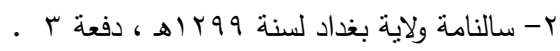

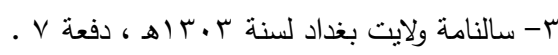

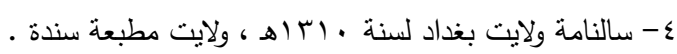

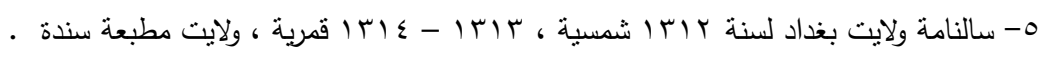

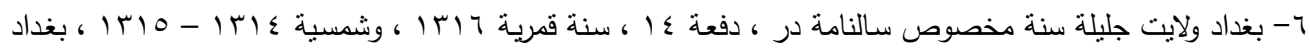

مطبعة سندة .

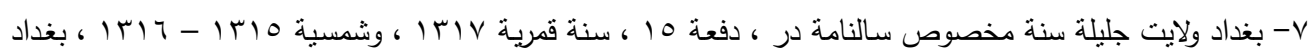

ولايتي مطبعة سندة .

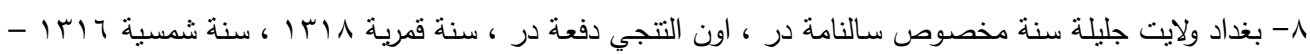

$$
\text { . IV }
$$

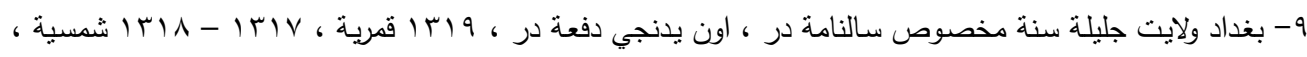

ولايت مطبعة سندة .

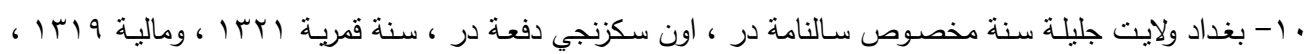

ولايت مطبعة سندة .

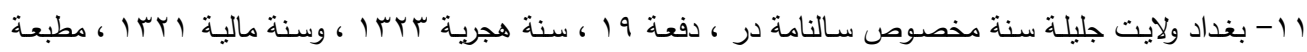

ولايت سندة . بغ ولاد

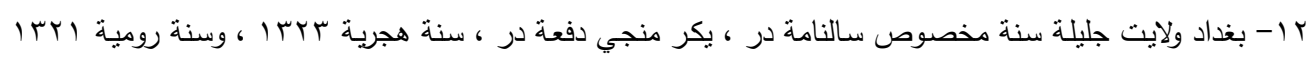


با - بغداد ولايت جليلة سنة مخصوص سـالنامة در ، يكرمي برنجي دفعة در ، سنة هجريـة هبrا ، ، وسنة روميـة

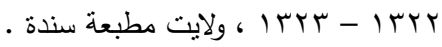

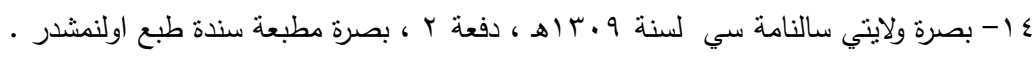

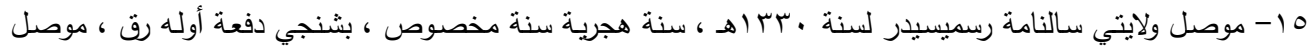

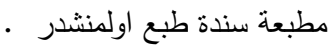

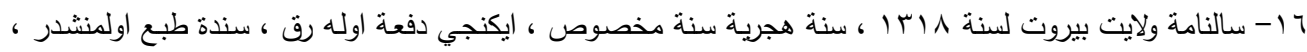

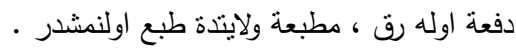

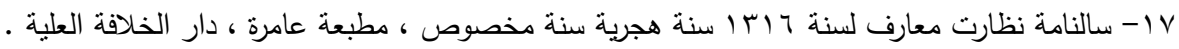

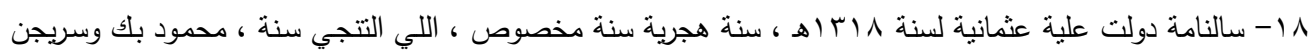

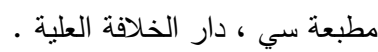

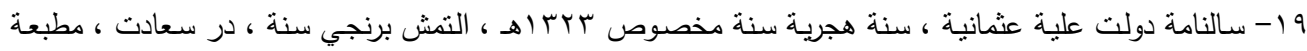
• احمد إحسان

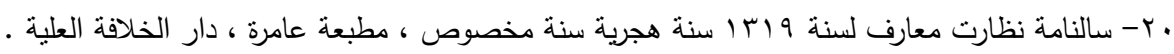

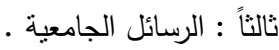

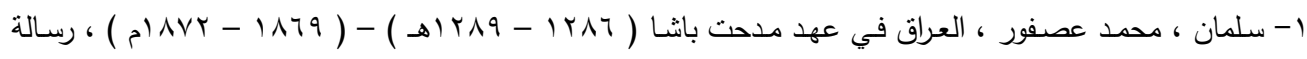

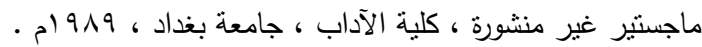

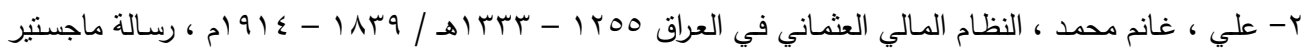

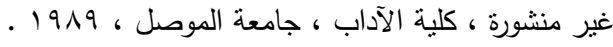

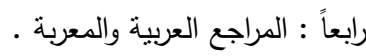

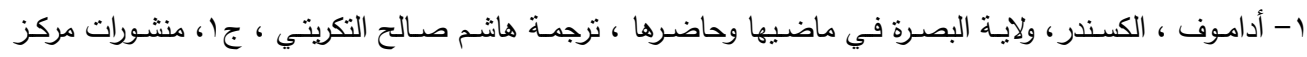

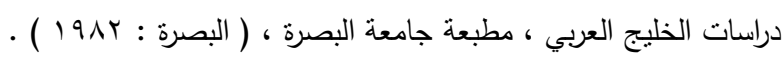

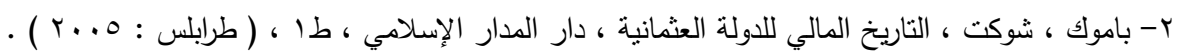

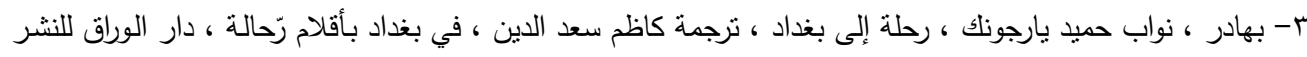

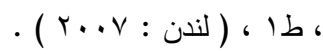

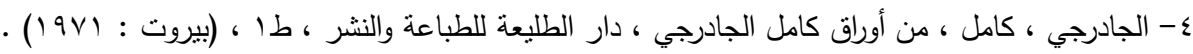

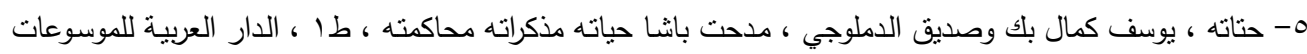

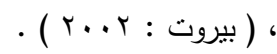

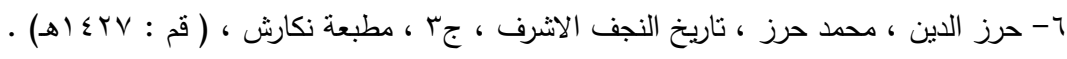

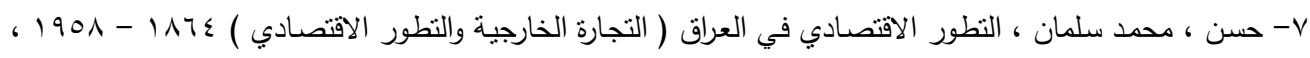

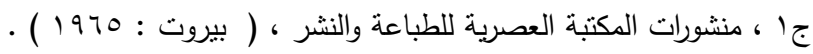

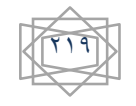




\section{العـــــــد الثاني والعشرون}

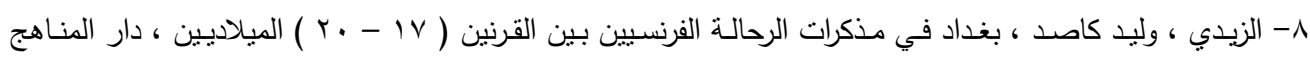

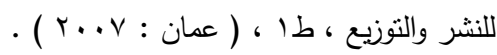

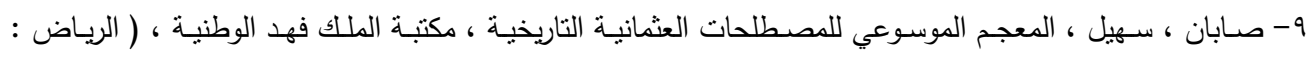

• 1- العارف ، عارف ، المفصل في تاريخ القس ، جا ، مطبعة المعارف ، طا ، ( القس : 1999 ) ) .

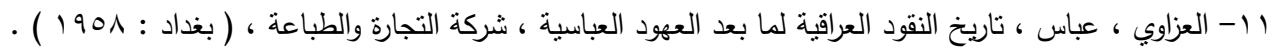

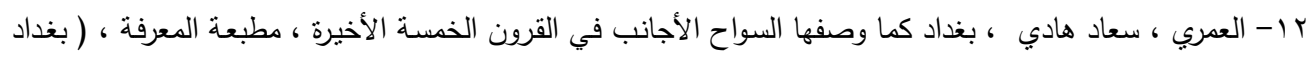
. (1905:

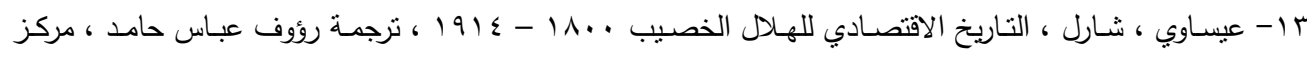

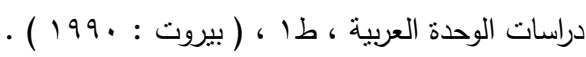

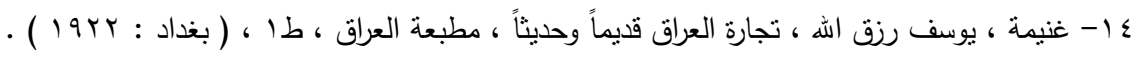

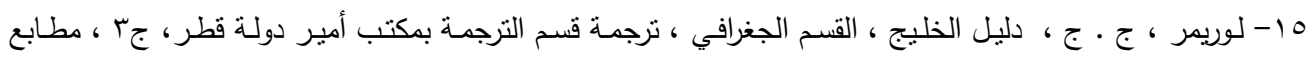

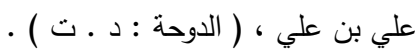
7 ا- لونكريك ، ستيفن هيمسلي ، أربعة قرون من تاريخ العراق الحديث ، نقله إلى العربية جعفر الخياط ، طء ، ( بغداد . (1971:

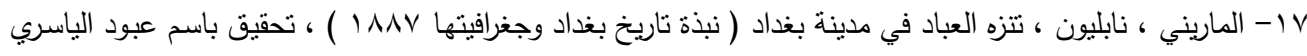

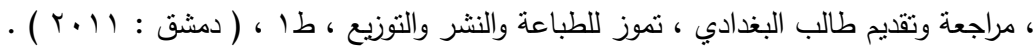

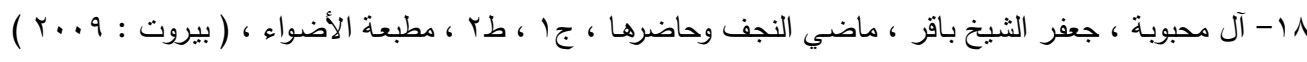

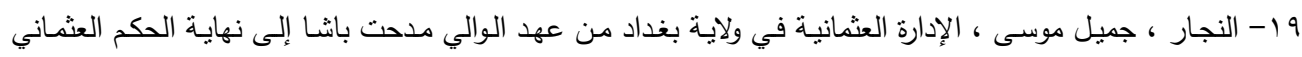

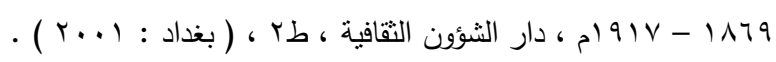

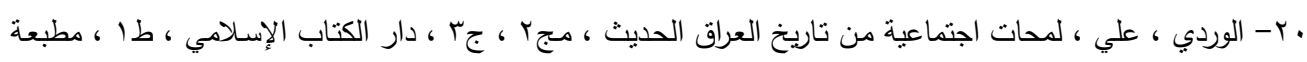

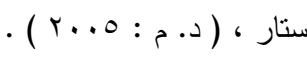

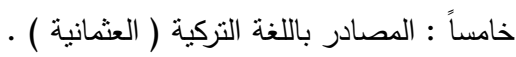

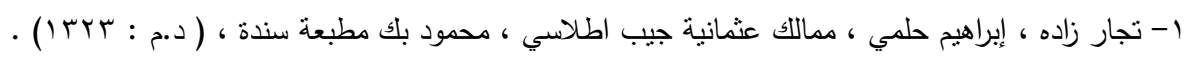

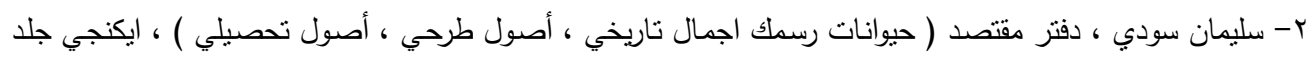

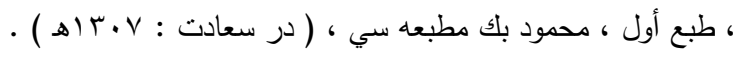

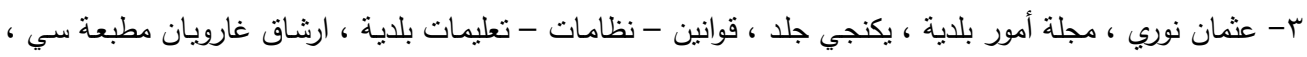

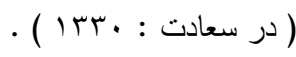
ع- فاضل ، إبراهيم ، بودجه ، حقوق مطبعة سي ، ( استانبول : كسب I ) ) 
1- Cuinet, Vital, Turguie d Asia, tome troisieme, ( Paris : 1894 ).

2- Curzon, George N, Persia and the Persian Question, Vol II , (London : 1892 ).

3- Guran , Tevfik, Osmanli Mali Istatistikleri Butceler 1841 - 1918 Ottoman Financial Statistics Budgets, ( Ankara : 2003 ).

4- Harries , Walter B , From Batum to Baghdad via Tiflis , Tabriz , and Persian Kurdistan , ( Edinburgh : n.d. )

5- Issawi , Charles, The Economic History pf the Middle East 1800 - 1914 , the university of Chicago press , ( Chicago : 1966 ).

6- Midhat Bey, Ali Haydar, The Life of Midhat Pasha, ( London : 1903 ) .

7- Shaw , Stanford J. , Ezel Kural Shaw , History of the Ottoman Empire and Modern

Turkey, vol II , Cambridge University press , ( Edinburgh : 2002 ).

8- Unat, Faik Resit, Hicri Tarihleri Miladi Tarihe Cevirme Kilavuzu , ( Ankara : 1988 ). 


\section{العـــــــد الثاني والعشرون}

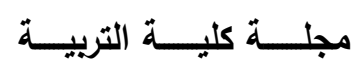

$$
\text { أ- البحوث والمقالات : الدوربات ( باللغة العربية ) : }
$$

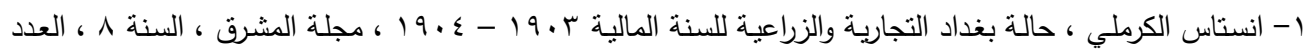

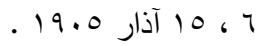

ب- الجليلي ، دحمد صديق ، التقويم الثمسي العثماني المسمى بالسنين المالية الرومية ، مجلة المجمع العلمي العراقي ،

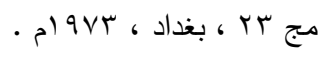

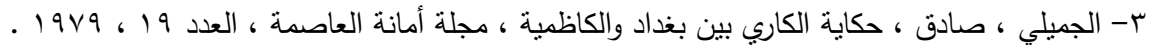

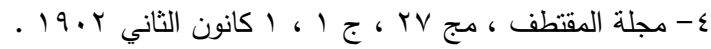

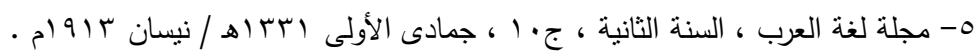

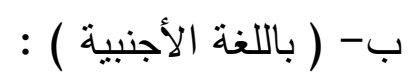

1- Keiko Kiyotaki, Ottoman State Finance : A study of Fiscal Deficits and Internal Debt In 1859 - 63 , working paper No. 90/05, London School of Economics, April , 2005 .

2- Shaw, Stanford J., The Nineteenth - Century Ottoman Tax Reforms and Revenue System , International Journal of Middle East Studies, Vol. 6 , No. 4 (Oct., 1975) .

\section{ت - الصحف العثمانية}

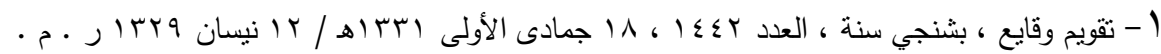

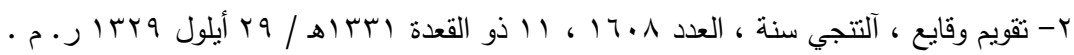

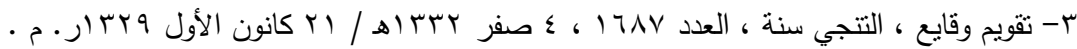

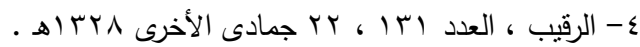

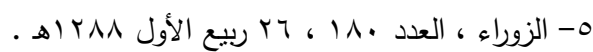

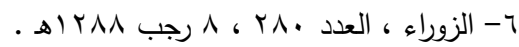

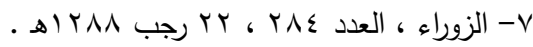

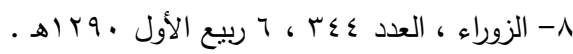

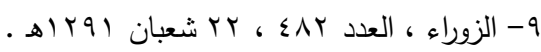

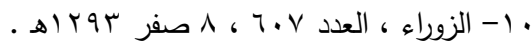

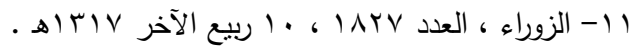

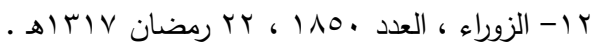

rا

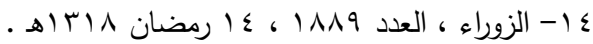




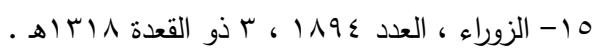

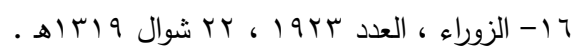

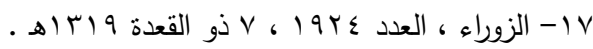

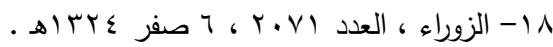

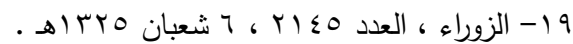

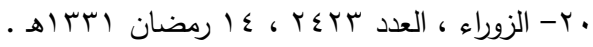

ا r- الزوراء ، العدد Tـ 


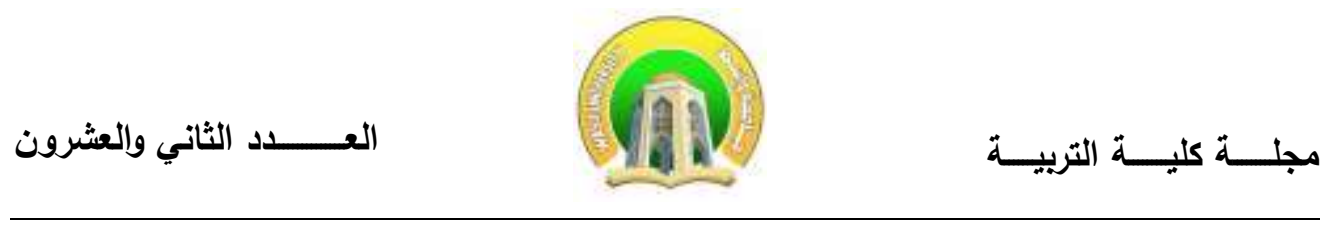

\begin{abstract}
:
Animals formed in the Ottoman Empire and multiple vilayets one of the main pillars of the economy Ottoman, Found in the Baghdad vilayet during the Ottoman era , many types of pets that were called the Covenant as the (civil animals), a sheep, goats, cows, buffalo and camels, as well as the animals that were used in the work agriculture, transport, mules and donkeys . The vilayet of Baghdad was primarily agriculturally . The vilayet's population, to livestock and domestic animals breeding, especially with the availability of appropriate conditions for breeding. Animal products have formed the second half of the agricultural production in the state, and the importance of animal products to only limited nutritional value, but surpassed the people of the state to adopt it in other areas.

Hence the choice of this research to demonstrate the financial and economic importance of service animals in the vilayet of Baghdad during the last Ottoman period 1869 - 1914 in the financial fields through a statement after the animals in the vilayet of Baghdad's budget, as well as to clarify the financial significance outside the budget through other financial income such as fees and taxes levied for the benefit of the state treasury. And the statement of its importance in the fields of industry, especially as some industries were adopted primarily on the basis of animal areas skin and wool, as it was animal products and wide input in the vilayet of Baghdad's foreign trade. The animals were used as a means for business travelers and cargo transport, As well as its importance in the military use of postal services in the vilayet of Baghdad
\end{abstract}

